\title{
Invited review: Current perspectives on eating and rumination activity in dairy cows ${ }^{1}$
}

\author{
K. A. Beauchemin ${ }^{2}$ \\ Agriculture and Agri-Food Canada, Lethbridge, Alberta, Canada T1J 4B1
}

\begin{abstract}
Many early studies laid the foundation for our understanding of the mechanics of chewing, the physiological role of chewing for the cow, and how chewing behavior is affected by dietary characteristics. However, the dairy cow has changed significantly over the past decades, as have the types of diets fed and the production systems used. The plethora of literature published in recent years provides new insights on eating and ruminating activity of dairy cows. Lactating dairy cows spend about $4.5 \mathrm{~h} / \mathrm{d}$ eating (range: $2.4-8.5 \mathrm{~h} / \mathrm{d}$ ) and $7 \mathrm{~h} / \mathrm{d}$ ruminating (range: $2.5-10.5 \mathrm{~h} / \mathrm{d}$ ), with a maximum total chewing time of $16 \mathrm{~h} / \mathrm{d}$. Chewing time is affected by many factors, most importantly whether access to feed is restricted, intake of neutral detergent fiber from forages, and mean particle size of the diet. Feed restriction and long particles $(\geq 19 \mathrm{~mm})$ have a greater effect on eating time, whereas intake of forage neutral detergent fiber and medium particles (4-19 $\mathrm{mm}$ ) affects rumination time. It is well entrenched in the literature that promoting chewing increases salivary secretion of dairy cows, which helps reduce the risk of acidosis. However, the net effect of a change in chewing time on rumen buffing is likely rather small; therefore, acidosis prevention strategies need to be broad. Damage to plant tissues during mastication creates sites that provide access to fungi, adhesion of bacteria, and formation of biofilms that progressively degrade carbohydrates. Rumination and eating are the main ways in which feed is reduced in particle size. Contractions of the rumen increase during eating and ruminating activity and help move small particles to the escapable pool and into the omasum. Use of recently developed low-cost sensors that monitor chewing activity of dairy cows in commercial facilities can provide information that is helpful in management decisions, especially
\end{abstract}

\footnotetext{
Received August 18, 2017.

Accepted January 11, 2018.

${ }^{1}$ Lethbridge Research and Development Center contribution no.

${ }^{2}$ Corresponding author: karen.beauchemin@agr.gc.ca
} 387-15084. when combined with other criteria. Although accuracy and precision can be somewhat variable depending on sensor and conditions of use, relative changes in cow behavior, such as a marked decrease in rumination time of a cow or sustained low rumination time compared with a contemporary group of cows, can be used to help detect estrus, parturition, and some illnesses. This review provides a comprehensive understanding of the dietary, animal, and management factors that affect eating and ruminating behavior in dairy cows and presents an overview of the physiological importance of chewing with emphasis on recent developments and practical implications for feeding and managing the modern housed dairy cow.

Key words: ruminating, behavior, physically effective fiber, rumen function, dietary particle size

\section{INTRODUCTION}

The process of chewing during eating and ruminating plays a vital role in maintaining high levels of feed intake and efficient digestive function in high-producing dairy cows. Ruminants chew their feed initially during eating, and swallowed feed is later regurgitated and remasticated through the process of rumination. As feed is chewed, particles are reduced in size and saliva is secreted to lubricate the bolus and enable swallowing. Saliva is an important buffer for the rumen, and thus chewing plays a key role in maintaining optimum rumen $\mathrm{pH}$ for microbial digestion of feed. Furthermore, physical breakdown of feed during mastication facilitates microbial colonization and passage of small particles from the rumen through the lower gastrointestinal tract. Optimum chewing time is needed to minimize the risk of rumen acidosis, enhance fiber digestion, and promote high levels of feed intake in dairy cows. Many early reviews laid the foundation for our understanding of the mechanics of chewing, the physiological role of chewing for the cow, and how chewing behavior is affected by changes in chemical composition and physical characteristics of the diet (e.g., Church, 1975; Welch, 1982; De Boever et al., 1990; Beauchemin, 1991a). However, the dairy cow has changed significantly over 
the past decades, as have the types of diets fed and the production systems used, and a significant body of work related to chewing in dairy cows has been published in recent years. The objective of this review is to provide an update on chewing behavior and its importance with emphasis on recent developments and practical implications for feeding and managing the modern housed dairy cow fed TMR.

\section{THE PROCESS OF EATING AND RUMINATING}

The mechanics of eating and ruminating in cattle are well understood (Church, 1975; Hofmann, 1988). As no significant change in that understanding has occurred in recent years, only a brief description of the process of eating and ruminating follows. During eating, the lips, teeth, and tongue of the cow are used to move feed into the mouth, where it is chewed. When cattle consume long-stemmed forage, the tongue pulls herbage into the mouth, whereas for concentrates or TMR from a feed trough, the lips play a more important role in conveying food into the mouth. Feed is chewed by lateral movements of the mandible, resulting in a grinding action that shears, rather than cuts, the feed. The feed is chewed by the molar teeth on one side of the mouth at a given time (Hofmann, 1988). A large amount of saliva is secreted during the eating process to enable a bolus to be formed and swallowed (Church, 1975).

Rumination (known colloquially as cud chewing) is a unique defining characteristic of ruminants. During rumination, digesta from the rumen is regurgitated, remasticated, and reswallowed (Ruckebusch, 1988). Mastication is slower and more consistent during rumination than during eating. During rumination, digesta is regurgitated from the reticulum through the cardia, into the esophagus, and then into the mouth. The regurgitation occurs as a result of an extra contraction of the reticulum that occurs just before the usual double contraction of the mixing cycle, combined with negative pressure within the trachea due to a sharp contraction of the diaphragm (Ruckebusch, 1988). Once in the mouth, some of the regurgitated liquid and small particles are swallowed, the remaining material is remasticated for about 30 to $70 \mathrm{~s}$, and the bolus is reswallowed. The next bolus is regurgitated 2 to $4 \mathrm{~s}$ later, and the entire cycle is repeated. Rumination bouts, which consist of series of boluses, last $30 \mathrm{~s}$ to $2 \mathrm{~h}$, with up to 20 rumination bouts each day. Generally, the longer the time spent ruminating, the longer the ruminating bouts are $(\mathrm{r}=0.51$; Dado and Allen, 1994). However, length of rumination bouts is not a good predictor of rumination time because many distractions can cause rumination to cease. The physiological maximum ru- mination time is about 10 to $12 \mathrm{~h} / \mathrm{d}$, which may occur in cattle fed high-fiber diets (Welch, 1982; De Boever et al., 1990). Most lactating dairy cows fed mixed diets seldom ruminate this long (Watt et al., 2015).

Rumination is stimulated by activation of tension receptors in the luminal surface of the reticulorumen (Ash and Kay, 1959; Leek, 1986). The tension receptors are excited by mild tactile stimulation and low to moderate distension of the rumen by the ruminal contents. However, extreme distension of the rumen (e.g., bloat) and various chemical stimuli actually inhibit ruminal contractions (Ash and Kay, 1959). For example, elevated concentrations of VFA and high osmotic pressure typically observed in early stages of acute acidosis can cause rumen stasis (Leek, 1986).

\section{DIFFERENCES IN CHEWING BEHAVIOR AMONG DAIRY BREEDS}

Aikman et al. (2008) reported important differences in chewing behavior between Holstein and Jersey cows of similar intake capacity when expressed relative to BW (DMI, \% of BW). As expected, Holsteins had greater daily DMI $(\mathrm{kg} / \mathrm{d})$ than Jerseys; however, eating time (min/d) did not differ between breeds. Thus, Jerseys spent more time eating per unit of ingested feed, which the authors suggest may have been partially due to the smaller mouths of Jerseys requiring them to have a larger number of mouthfuls to process an equal volume of feed. The duration and number of meals consumed were similar for the 2 breeds, but the meals consumed by Jerseys tended to be distributed more evenly throughout each 24-h period, providing a more regular supply of feed and saliva to the rumen. Holsteins spent more time ruminating per day compared with Jerseys, but Jerseys spent more time ruminating per unit of ingested feed. Dividing the DMI by the number of boluses regurgitated during rumination revealed that bolus size in Holsteins was greater than that in Jerseys (26.0 and $17.5 \mathrm{~g}$ of DM, respectively). The study also showed that passage of feed through the gastrointestinal tract was faster in Jerseys compared with Holsteins, which may have resulted from the more thorough chewing of feed causing more effective particle size reduction. Thus, the physiological maximum chewing time of cattle is likely to penalize Holsteins more than Jerseys because they have a greater volume of feed to process.

\section{FACTORS AFFECTING EATING BEHAVIOR}

The eating behavior of dairy cows had been described previously (Dulphy et al., 1979; Campling and Morgan, 1981; Beauchemin, 1991a; Albright, 1993), but recent mechanization of feeding equipment and behavior re- 
cording have given rise to further important insights for the modern dairy cow. Eating time differs from feeding time in that the latter represents meals and includes periods of inactivity, whereas eating time refers solely to the time spent prehending, chewing, and swallowing feed. Meals comprise eating bouts interspersed with periods of noneating (making up 30-50\% of meal time). In a study of 515 dairy cows in 7 experiments with more than 1.2 million cow visits to a feeder, cows consumed an average of 7.7 meals per day, with each meal separated by at least 29 min (De Mol et al., 2016).

The time dairy cattle spend eating is highly variable when combined across experimental conditions. In a recent summary of treatment means for dairy cows from peer-reviewed publications, White et al. (2017) reported a mean eating time of $284 \mathrm{~min} / \mathrm{d}(\mathrm{n}=182)$, ranging from 141 to $507 \mathrm{~min} / \mathrm{d}$ (Table 1). Part of the variation may be due to the slightly different criteria used among studies to define eating time, but eating time is also highly affected by feed management, DMI, physical and chemical composition of the diet, and inherent variability among animals.

\section{Feeding Management}

Greatest feeding activity typically occurs after feed is delivered (King et al., 2016) or pushed up (MillerCushon and DeVries, 2017) throughout the day. Thus, frequent delivery of TMR tends to promote feeding activity and a more even distribution of feeding time throughout the day, although DMI is not necessarily increased (Miller-Cushon and DeVries, 2017). With noncompetitive feeding situations and unrestricted access to feed, rate of eating during a meal is generally rapid at the start and declines toward the end as ap- petite is satiated (Suzuki et al., 1969) and as salivary flow declines (Bailey, 1961), especially for more fibrous feeds. Cows will increase their feeding intensity as the amount of feed and access to feed decrease (Campling and Morgan, 1981). Competitive feeding situations increase the eating rate $(\mathrm{kg}$ of $\mathrm{DM} / \mathrm{min})$ and decrease the total time spent eating each day (Proudfoot et al., 2009). Dry matter intake may also decrease with competition at the feed bunk or limited time to access feed if the increase in eating rate does not fully compensate for restricted resources (Munksgaard et al., 2005). With increased limited access to feed, cows tend to eat fewer but longer meals with greater nonfeeding time within meals (Crossley et al., 2017). Older cows eat faster than younger cows (Dado and Allen, 1994); thus, restricting feed bunk access will have a greater effect on younger cows that may be less dominant.

Thus, total time spent eating and pattern of eating each day depend foremost on whether cows have free access to feed. Diet composition affects eating behavior as well, but to a lesser extent. Cows modify their feeding behavior to consume feed in a shorter period when necessary, which indirectly allows them to better compete for feed and maintain DMI (Crossley et al., 2017). Subordinate cows are particularly affected by increased competition (DeVries et al., 2004).

\section{Feed Intake}

In the large study of De Mol et al. (2016) described above, the correlation between eating time and feed intake was 0.53 in a TMR system and 0.56 in a partial TMR system. Thus, monitoring eating time on farm, especially when combined with other information (milk yield, BW, cow size; Connor, 2015), could be useful in

Table 1. Summary of treatment means for DMI, chewing activity, and mean rumen $\mathrm{pH}$ of dairy cows from peer-reviewed publications

\begin{tabular}{|c|c|c|c|c|c|}
\hline Item & No. & Mean & $\mathrm{SD}$ & Minimum & Maximum \\
\hline \multicolumn{6}{|l|}{ White et al. (2017) } \\
\hline DMI, $\mathrm{kg} / \mathrm{d}$ & 224 & 22.7 & 3.3 & 14.7 & 31.6 \\
\hline Milk production, $\mathrm{kg} / \mathrm{d}$ & 197 & 34.1 & 7.4 & 14.2 & 51.3 \\
\hline \multicolumn{6}{|l|}{ Chewing time, $\mathrm{min} / \mathrm{d}$} \\
\hline Eating & 182 & 284 & 77.3 & 141 & 507 \\
\hline Ruminating & 179 & 436 & 68.4 & 236 & 610 \\
\hline Total & 175 & 717 & 115 & 396 & 973 \\
\hline Mean rumen pH & 181 & 6.12 & 0.27 & 5.44 & 6.83 \\
\hline \multicolumn{6}{|l|}{ Zebeli et al. (2006) } \\
\hline DMI, $\mathrm{kg} / \mathrm{d}$ & 131 & 23.0 & 1.9 & 16.9 & 28.3 \\
\hline Milk production, $\mathrm{kg} / \mathrm{d}$ & 131 & 34.9 & 5.84 & 23.1 & 49.3 \\
\hline \multicolumn{6}{|l|}{ Chewing time, $\min / \mathrm{d}$} \\
\hline Eating & $\mathrm{NR}^{1}$ & NR & NR & NR & NR \\
\hline Ruminating & 99 & 434 & 82.5 & 151 & 632 \\
\hline Total & 99 & 691 & 111.4 & 425 & 969 \\
\hline Mean rumen $\mathrm{pH}$ & 100 & 6.09 & 0.20 & 5.30 & 6.59 \\
\hline
\end{tabular}

${ }^{1}$ Not reported. 
estimating individual feed intake. Because of the association between DMI and eating time, the effects of dietary components such as NDF content or particle size are more highly related to eating time when expressed as intake of components rather than concentration.

\section{Chemical and Physical Characteristics of the Diet}

Concentrate feeds, when offered alone, are consumed rapidly, whereas forages are consumed slowly in frequent meals of small amounts (Beauchemin et al., 2008). Yet, when concentrates and forages are offered as a TMR, increasing forage proportion does not necessarily increase eating time because DMI may decrease (Yang and Beauchemin, 2009). Silage is consumed more rapidly than long-stemmed hay on an as-fed basis because of its smaller particle size and greater moisture content and the ease of bolus formation (Beauchemin et al., 2008). Because hay is chewed slowly, median particle size of the swallowed bolus can actually be less than that of swallowed silage (Gill et al., 1966). Therefore, feed particle size does not necessarily reflect the particle size of the swallowed feed bolus (Schadt et al., 2012) or the feces (Maulfair et al., 2011).

The correlation between eating time and dietary NDF content or forage NDF (FNDF) content is low across studies ( $\mathrm{r} \leq 0.12$; White et al., 2017) because fiber content does not account for differences in intake. For example, Dann et al. (2015) fed diets containing 50 and $65 \%$ forage (DM basis) and reported that DMI tended to be lower for the higher forage diet; hence, eating and ruminating times were similar for the 2 diets. When chewing time was expressed relative to intake, eating and ruminating times $(\mathrm{min} / \mathrm{kg}$ of $\mathrm{DMI}$ ) were greater for the high-forage diet. The relationship between eating time $(\mathrm{min} / \mathrm{d})$ in dairy cows and dietary FNDF intake is shown in Figure 1 and indicates an overall positive association but with considerable scatter because numerous other factors affect eating time.

A general association, although also highly variable, exists between particle size of the diet and eating time. Increasing particle size of silage increased eating time ( $\mathrm{min} / \mathrm{d}, \mathrm{min} / \mathrm{kg}$ of DM) of dairy cows in many studies (Soita et al., 2000; Yang et al., 2001b; Kononoff and Heinrichs, 2003; Kowsar et al., 2008; Akbari-Afjani et al., 2014; Alamouti et al., 2014) but not all (Kononoff et al., 2003b; Alamouti et al., 2009). White et al. (2017) reported that the correlation between eating time (min/d) and dietary content of long particles retained on a $19-\mathrm{mm}$ sieve across studies was moderate $(\mathrm{r}=$ $0.45, P<0.05)$. The relationship between eating time (min/kg of DMI) in dairy cows and mean particle size (MPS) of the diet across studies is plotted in Figure
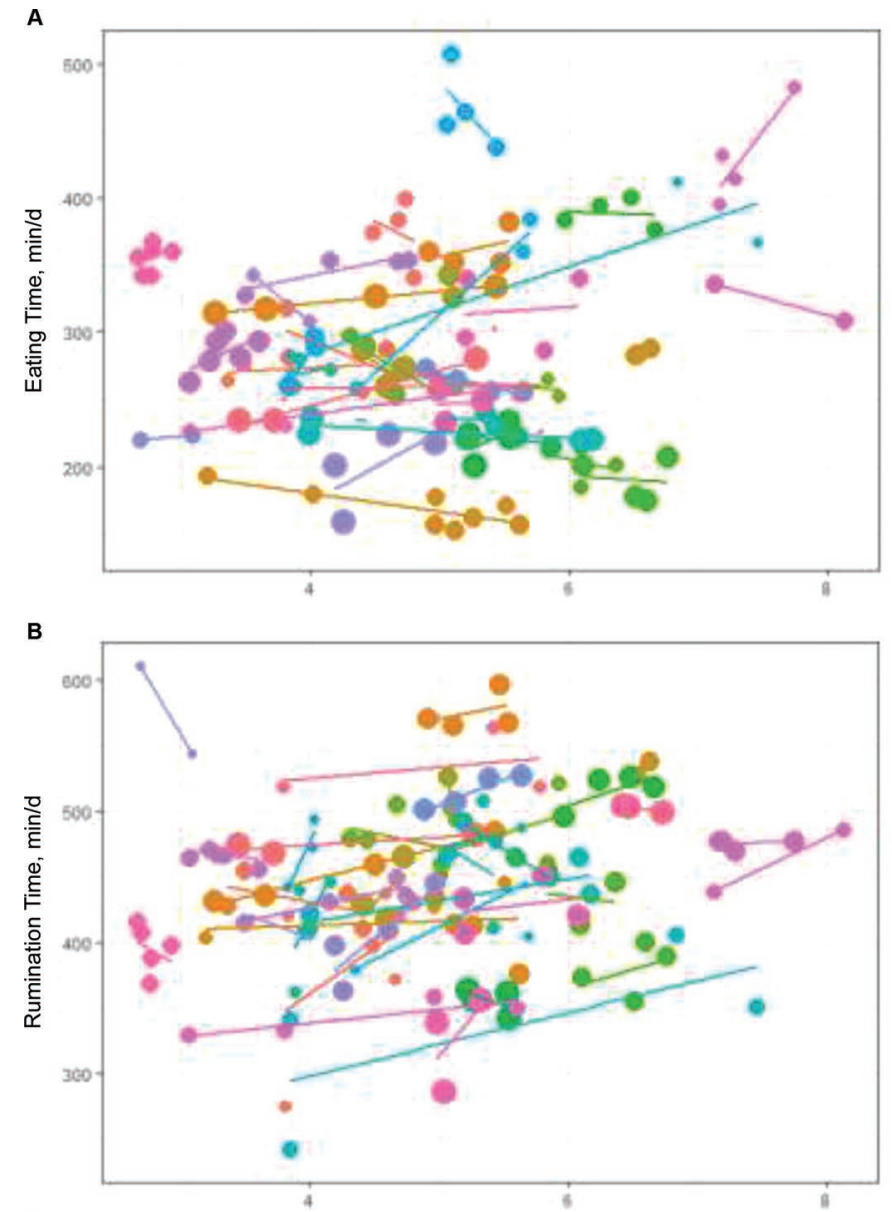

C

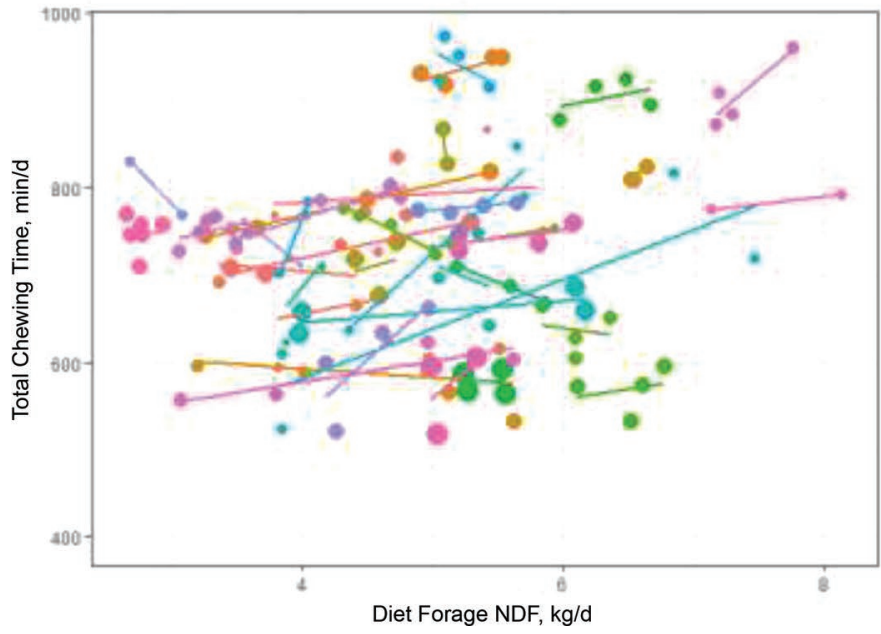

Figure 1. Eating, rumination, and total chewing time $(\mathrm{min} / \mathrm{d})$ and forage NDF intake $(\mathrm{kg} / \mathrm{d})$ for lactating dairy cows summarized from the literature. Points are treatment means and are colored by study and sized by weighting used in the meta-regression; connecting lines represent the regression lines within study. Figure from R. White, Virginia Tech University, unpublished data; used with permission. Color version available online. 


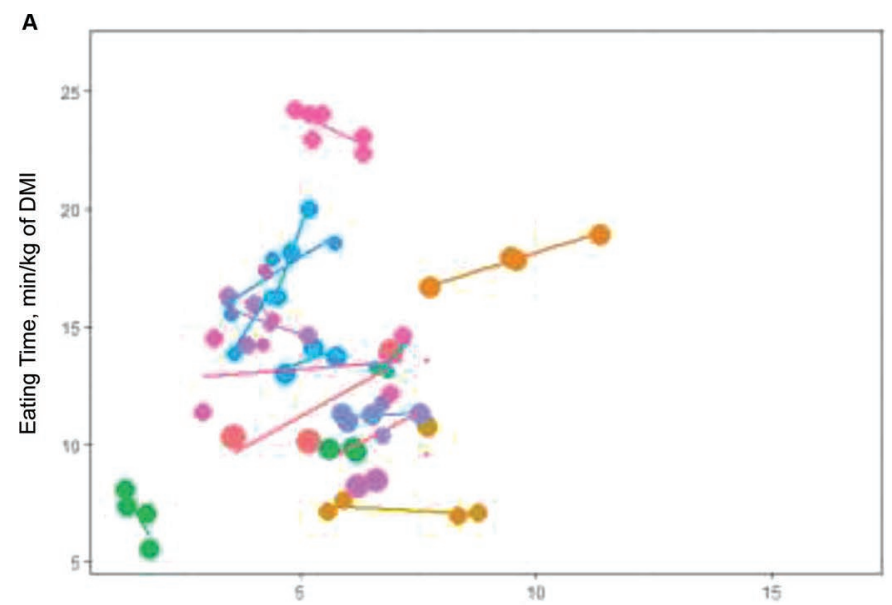

B

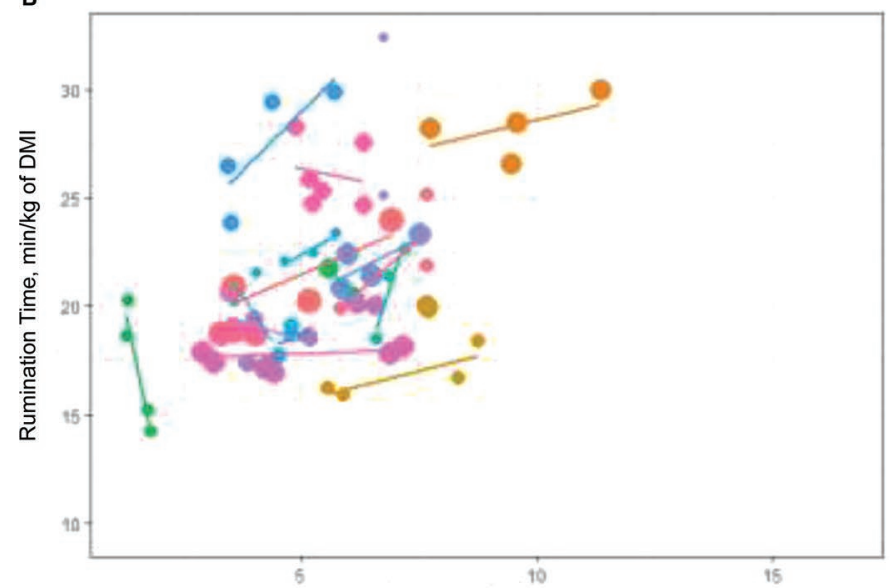

C

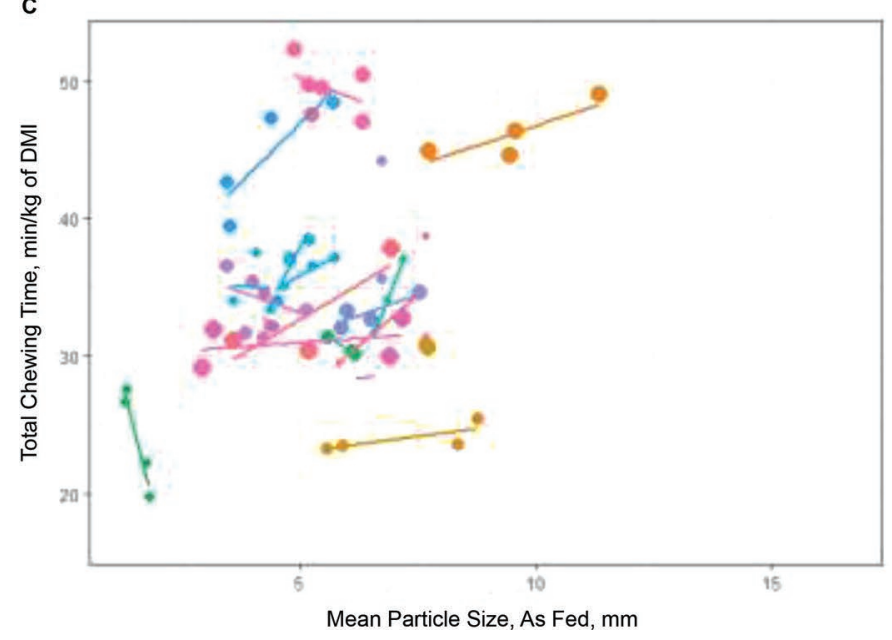

Figure 2. Eating, rumination, and total chewing time $(\mathrm{min} / \mathrm{kg}$ of DMI) and mean particle size of the diet for lactating dairy cows summarized from the literature. Points are treatment means and are colored by study and sized by weighting used in the meta-regression; connecting lines represent the regression lines within study. Figure from R. White, Virginia Tech University, unpublished data; used with permission. Color version available online.
2 and indicates an overall positive but highly variable association.

\section{Animal Variation}

There is inherent variability among animals in time spent eating. The coefficient of variation $(\mathbf{C V})$ for eating time $(\mathrm{min} / \mathrm{d}$ ) among cows is about 17\% (Dado and Allen, 1994), but the CV is 3- to 4-fold greater for feeding time. Some meal characteristics are highly variable among cows. Frequency of meals (no./24 h) and overall meal duration are unique for individual cows, whereas eating rate and meal size are fairly consistent among cows (Vasilatos and Wangsness, 1980).

\section{Complementarity Between Eating and Ruminating Time}

There can be a compensatory relationship between eating and ruminating time. Dado and Allen (1994) reported that for dairy cows with unrestricted feed access the correlation coefficient between eating time and ruminating time was -0.62 , indicating that cows that spend less time eating tend to ruminate longer. A similar inverse relationship was reported for cows with decreased eating time due to feed restriction or diet composition; rumination time increased to compensate for the longer particle size of swallowed feed due to feed restriction (Dulphy et al., 1979; Campling and Morgan, 1981). Thus, total chewing time is less variable than eating or ruminating time. However, this compensatory effect does not occur if cows are ruminating near their physiological maximum, which is sometimes the case for high-producing dairy cows. Hence, the correlation between eating and ruminating time for dairy cows was relatively low when examined across studies (e.g., $\mathrm{r}=$ $0.27, P<0.05$; White et al., 2017). Maximum total chewing time for dairy cows is estimated at about 16 h/d (Zebeli et al., 2006; Jensen et al., 2016; White et al., 2017).

\section{FACTORS AFFECTING RUMINATING BEHAVIOR}

Most rumination occurs at night when cows are at rest, but cattle also ruminate throughout the day when not interrupted by management such as feeding and milking (Grant et al., 1990; Dado and Allen, 1994; Paudyal et al., 2016). Schirmann et al. (2012) reported that rumination time peaked approximately $4 \mathrm{~h}$ after feeding and that periods of rumination were also associated with time spent lying down. However, as rumination time increases, proportionally less rumination occurs at night and when cows are lying down (Stone et al., 2017). Some studies report greater rumination time in 
multiparous compared with primiparous cows, but this difference appears to be due to differences in DMI as rumination time adjusted for intake of primiparous cows is usually less than or similar to that of multiparous cows (Beauchemin and Rode, 1994, 1997; Dado and Allen, 1994; Beauchemin and Rode, 1997; Maekawa et al., 2002b; Kowsar et al., 2008).

In summarizing the literature for dairy cows, White et al. (2017) reported that mean ruminating time was $436 \mathrm{~min} / \mathrm{d}(\mathrm{n}=179)$, ranging from 236 to $610 \mathrm{~min} / \mathrm{d}$, and Zebeli et al. (2006) reported that mean ruminating time was $434 \mathrm{~min} / \mathrm{d}(\mathrm{n}=99)$, ranging from 151 to 630 $\mathrm{min} / \mathrm{d}$ (Table 1 ). The large variability in ruminating time across treatment means occurred for many reasons, including measurement technique (see "Rumination Monitoring On Farm to Assess Cow Health"), inherent variability among animals (De Boever et al., 1990), and physical and chemical composition of the diet.

\section{Animal Variability}

The CV for rumination time (min/d) among animals was reported as $16 \%$ in 12 cows monitored in a shortterm study using a pressure transducer placed under the cow's jaw (Dado and Allen, 1994) and as high as $48 \%$ when recorded for 79 cows for 1,254 cow-days using an acoustic system (Byskov et al., 2015). The greater CV in the latter study may have been partially due to the lower accuracy of some sensor measurement techniques (see "Rumination Monitoring On Farm to Assess Cow Health").

\section{Milk Yield and DMI}

Rumination time is positively associated with milk production. Stone et al. (2017) reported a weak rela- tionship between rumination time and milk yield $(\mathrm{n}=$ 36 cows, $\mathrm{r}=0.22, P<0.01$ ), whereas Kaufman et al. (2018) reported that daily milk yield of cows in early lactation was moderately correlated with rumination time $(\mathrm{r}=0.37$ to 0.69 depending on parity and DIM). The positive association between rumination time and milk yield may be indirectly related to DMI. However, the relationship between DMI and rumination is also weak because of the overriding effects of diet composition. For example, both Schirmann et al. (2012) and Clément et al. (2014) reported that rumination time and DMI were not correlated across cows. Thus, the main drivers of rumination time are chemical and physical characteristics of the diet.

\section{Chemical and Physical Characteristics of the Diet}

Rumination time is highly influenced by NDF intake, particle size of the diet, fragility (hardness) of feed that imparts resistance of feed to chewing (Nørgaard et al., 2011), and the indigestibility of the fiber. There are complex interactions among these factors; thus, the correlation between rumination time and individual dietary factors is only low to moderate. Rumination time is more highly correlated with intake of NDF rather than with NDF content. The correlation coefficient between rumination time and NDF content of the diet is $<0.10$ (Yang and Beauchemin, 2007, 2009; White et al., 2017). Correlations between rumination and FNDF percentage are somewhat greater (Zebeli et al., 2006, $\mathrm{r}=0.46, P<0.05$; Byskov et al., 2015, $\mathrm{r}=0.28, P$ $<0.001$; White et al., 2017, $\mathrm{r}=0.19, P<0.05)$, as is the case with dietary forage proportion (White et al., $2017, \mathrm{r}=0.15, P<0.05)$ and dietary silage proportion (White et al., 2017, $\mathrm{r}=0.21, P<0.05$; Table 2). Accounting for intake further improves the relationship;

Table 2. Correlations between diet, chewing, and rumen $\mathrm{pH}$ variables ${ }^{1}$

\begin{tabular}{lcccc}
\hline Item & $\begin{array}{c}\text { Eating time, } \\
\text { min/d }\end{array}$ & $\begin{array}{c}\text { Ruminating time, } \\
\text { min/d }\end{array}$ & $\begin{array}{c}\text { Chewing time, } \\
\text { min/d }\end{array}$ & $\begin{array}{c}\text { Mean } \\
\text { rumen pH }\end{array}$ \\
\hline DMI & -0.06 & $0.19^{*}$ & 0.07 & -0.12 \\
Ruminating time, min/d & $0.27^{*}$ & 1.00 & $0.77^{*}$ & -0.12 \\
Eating time, min/d & 1.00 & $0.27^{*}$ & $0.82^{*}$ & -0.03 \\
Total chewing, min/d & $0.82^{*}$ & $0.77^{*}$ & 1.00 & -0.09 \\
pH & -0.03 & -0.12 & -0.09 & 1.00 \\
Starch, \% of DM & $-0.22^{*}$ & 0.09 & -0.11 & $0.14 \dagger$ \\
NDF, \% of DM & 0.12 & $-0.15^{*}$ & 0.001 & $0.19^{*}$ \\
CP, \% of DM & $-0.22^{*}$ & $0.14 \dagger$ & -0.05 & -0.11 \\
Forage NDF, \% of DM & 0.10 & $0.19^{*}$ & $0.19^{*}$ & 0.12 \\
Forage, \% of DM & 0.12 & $0.15^{*}$ & $0.15^{*}$ & -0.06 \\
TMR particles retained on sieve & & & & $0.34^{*}$ \\
$\quad 19$ mm, \% of DM & $0.45^{*}$ & 0.17 & $0.28^{*}$ & 0.14 \\
8 mm, \% of DM & 0.03 & $0.38^{*}$ & 0.001 & $-0.16^{*}$ \\
Silage, \% of DM & $-0.13 \dagger$ & $0.21^{*}$ & & \\
${ }^{1}$ Data from White et al. $(2017) ;$ used with permission. & & &
\end{tabular}


correlation between rumination time and NDF intake was 0.35 to 0.54 in studies by Yang and Beauchemin (2007, 2009) and Yang et al. (2001b). The relationship between ruminating time and dietary FNDF intake $(\mathrm{kg} / \mathrm{d})$ across studies is shown in Figure 1.

Increasing dietary FNDF intake can be achieved through an increase in the forage:concentrate $(\mathbf{F}: \mathbf{C})$ ratio, which increases both FNDF intake and particle size of the diet. Rumination time relative to FNDF intake is highly variable, ranging from 75 (Yang and Beauchemin, 2009) to 180 (Byskov et al., 2015) min/ $\mathrm{kg}$ of FNDF depending on the forage source. Byskov et al. (2015) showed across 27 different diets that each additional kilogram of FNDF intake increased rumination time above the mean by about $22 \mathrm{~min} / \mathrm{d}$, which is similar to the 17 to $21 \mathrm{~min} / \mathrm{d}$ reported by Yang and Beauchemin $(2007,2009)$ for diets comprising alfalfa silage and $21 \mathrm{~min} / \mathrm{d}$ reported by Beauchemin and Rode (1994) for diets comprising alfalfa hay.

Increasing particle size of the TMR increases rumination time, with the response diminishing as particle size increases. No further increase in rumination time occurs after a certain particle size. It is difficult to precisely define that threshold particle size because MPS represents a particle size distribution, the method of determining particle size affects MPS, and the effects of forage particle size depend on inclusion level in the diet (Nasrollahi et al., 2016). However, the most dramatic reductions on chewing time occur when MPS is very fine (MPS $<5 \mathrm{~mm}$ ). Allen (1997) suggested that moderate or no further increase in rumination time occurs when particle size is increased above a threshold MPS of $10 \mathrm{~mm}$ (Allen, 1997). In a meta-analysis of 86 studies, Nasrollahi et al. (2016) showed that decreasing forage MPS in dairy cow diets from an average of 10.0 \pm 4.9 to $6.7 \pm 4.11 \mathrm{~mm}$ lowered eating, rumination, and total chewing time by 19,28 , and $44 \mathrm{~min} / \mathrm{d}$, respectively $(P<0.01)$. The authors also reported that the effects of forage particle size were strongly affected by level of inclusion of forage in the diet and method of preserving forages, with decreasing forage particle size having greater influence at high inclusion levels and in hay-based diets. Thus, fine grinding and chopping of feed usually decreases rumination time (Soita et al., 2000; Yang et al., 2001b; Krause et al., 2002b), whereas coarse chopping may have no effect on rumination time (Grant et al., 1990; Alamouti et al., 2009).

Overall, increasing particle size of the diet is more effective at promoting rumination in diets containing greater $\mathrm{F}$ : $\mathrm{C}$ ratio because the resulting increase in intake of long particles is greater for higher forage diets. Similarly, increasing the F:C ratio of the diet is more effective at promoting rumination when forages are longer in particle size (Yang and Beauchemin, 2007, 2009).

In general, increasing particle size of the diet seems to have less effect on promoting rumination time compared with eating time. This is likely because the additional mastication during eating can minimize differences in particle size of the swallowed bolus and hence reduce the need for additional particle size reduction during rumination. For example, Kahyani et al. (2013) fed dairy cows $25 \%$ of dietary intake as alfalfa hay chopped fine, medium, or coarse, and eating time $(\mathrm{min} / \mathrm{d}, \mathrm{min} / \mathrm{kg}$ of $\mathrm{DM}, \mathrm{min} / \mathrm{kg}$ of $\mathrm{NDF}$ ) increased linearly but rumination time was not affected by diet. Similar effects of forage particle size on eating and ruminating time were reported by others (Yang et al., 2001b; Kowsar et al., 2008; Akbari-Afjani et al., 2014; Alamouti et al., 2014). However, increased eating time does not always eliminate the need for longer rumination time per kilogram of DM when intake of long forage particles is increased through increased $\mathrm{F}: \mathrm{C}$ ratio (Jiang et al., 2017) or particle size (Zhang et al., 2010; Kammes and Allen, 2012). For example, Jiang et al. (2017) fed dairy cows 4 diets that ranged from 40 to $70 \%$ forage. Eating time increased ( $\mathrm{min} / \mathrm{d}, \mathrm{min} / \mathrm{kg}$ of $\mathrm{DM}, \mathrm{min} / \mathrm{kg}$ of $\mathrm{NDF}$ ) with increasing $\mathrm{F}: \mathrm{C}$ ratio of the diet. Rumination time per kilogram of DMI was also increased, indicating that longer chewing during eating did not fully reduce the need for additional mastication during rumination. However, total rumination time was not affected in that study because DMI decreased with increasing dietary forage content.

Particle size of TMR can be measured in various ways, but it is not clear which physical measure provides the most useful estimate of physiological response. Mean particle size can be reported as the geometric mean length (mean diagonal size of screen through which $50 \%$ cumulative weight of sample passes) and standard deviation (ANSI, 1998). Yang et al. (2001b) reported that the correlation between MPS and rumination time was 0.40. Mertens (1997) suggested that particles retained on a $1.18-\mathrm{mm}$ sieve using a dry sieving method promoted chewing, which was the basis for developing the concept of effective NDF. The effective NDF concept later evolved to physically effective NDF (peNDF). The Penn State Particle Separator, originally with 3 sieves (openings of 19.0, 8.0, and $1.18 \mathrm{~mm}$ ) and a bottom pan and more recently with a 4-mm sieve replacing the 1.18-mm sieve, has been widely adopted on farm to measure particle length of feeds (Kononoff et al., 2003a; Heinrichs, 2013). Physically effective NDF is calculated as the NDF content multiplied by the physical effectiveness factor (pef), estimated as the total proportion of material retained on both 19- and 8-mm screens (pef 
$\geq 8$ ) or all 3 sieves (pef $\geq 1.18$ or pef $\geq 4$ ). Other methods of determining particle size include the Z-Box tool with interchangeable sieves (developed at the William H. Miner Agricultural Research Institute, Chazy, NY; Cotanch and Grant, 2006), the Ro-Tapp dry sieving device that uses a stack of sieves with vertical shaking (W. S. Tyler, Mentor, OH; Mertens, 1997), and the nonportable Wisconsin separator that is mechanically operated and uses a horizontal shaking motion (ASABE, 2007). The Z-Box was designed to correlate with the proportion of particles retained above a $1.18-\mathrm{mm}$ sieve when separated using the Ro-Tapp dry sieving device. Cotanch and Grant (2006) suggested that a 3.18mm screen should be used for corn silage and TMR and a 4.76-mm screen should be used for hay crop silage.

In summarizing the literature, Zebeli et al. (2006) reported that the correlations between rumination time and dietary proportion of peNDF (peNDF $\geq 1.18$, peNDF $\geq 8)$ were $\leq 0.54(P<0.05)$, whereas White et al. (2017) reported that correlations between rumination time and proportion of particles retained on 8- and 19 -mm screens were $0.38(P<0.05)$ and $0.17(P>$ $0.05)$, respectively.

In addition to NDF and particle size, inherent characteristics of forage fiber affect chewing (Nørgaard et al., 2011). Forage fiber that is less digestible will lead to increased rumination time per kilogram of ingested DM and NDF. This can be seen in a study by Sá Neto et al. (2014), who compared diets containing corn silage, sugarcane silage, and a mixture of the 2 forages. The FNDF content, pef, and MPS of the diets were relatively similar. However, chewing per FNDF intake $(\mathrm{min} / \mathrm{kg})$ and per peNDF $\geq 8$ intake $(\mathrm{min} / \mathrm{kg}$ ) increased with increasing level of sugarcane silage in the diet, suggesting that at the same content of FNDF and particle size, sugarcane silage had a greater capacity than corn silage to stimulate chewing. This difference was ascribed to the greater indigestible NDF (iNDF; 288-h ruminal in situ incubation) content of sugarcane compared with corn silage (18.9 vs. $30.0 \%$ $\mathrm{DM}$ ), which is indicative of low NDF digestibility. The iNDF fraction represented almost $50 \%$ of NDF in sugarcane, compared with approximately $35 \%$ of NDF in corn silage. Fustini et al. (2017) compared the effects of high- and low-digestibility alfalfa hay in the diet of dairy cows with soyhulls added to each forage source to produce high- and low-iNDF diets (240-h in vitro analysis). The DMI increased, as did rumination time for diets containing more digestible alfalfa hay, but no effect of alfalfa digestibility or iNDF content of diets on rumination time was observed after adjusting for intake ( $\mathrm{min} / \mathrm{kg}$ of DMI). In the Nordic feed evaluation system, the eating index of a feed is proportional to its NDF concentration $(\mathrm{g} / \mathrm{kg}$ of $\mathrm{DM})$ and theoretical chop length $(\mathrm{mm})$, whereas ruminating index is proportional to these same factors and a linear function of iNDF (Nørgaard et al., 2011).

\section{PREDICTING CHEWING TIME}

Predicting the time that cows spend chewing or ruminating can be a valuable management tool in terms of optimizing cow health, but the accuracy can be low because of the many interacting factors. Chewing time of feeds, or chewing index (CI; $\mathrm{min} / \mathrm{kg}$ of DM), is highly variable. Jensen et al. (2016) reported for 80 diets that CI of TMR averaged 35.1, ranging from 24.6 to 62.5 , whereas CI of diets with separate ingredient feeding averaged 38.2, ranging from 30.2 to 49.4. In the meta-analysis of Zebeli et al. (2006), CI ranged from 17.9 to $47.1(\mathrm{n}=99)$, with a mean of 30.1. A CI $\geq 30$ has been considered by some as desirable for optimum rumen function, as discussed by Zebeli et al. (2006). The variability in chewing time for diets is a clear indication that other factors, including diet composition, affect chewing time of feeds as previously discussed.

Various authors have developed equations to predict chewing and ruminating time of dairy cows with relatively low precision and accuracy (Supplementary File S1, https://doi.org/10.3168/jds.2017-13706; Table 3). Allen (1997) predicted chewing time $(668 \pm 126 \mathrm{~min} / \mathrm{d}$; mean \pm SD) from DMI, FNDF content, and MPS $\left[\mathrm{R}^{2}\right.$ $=0.69 ;$ root mean squared error $(\mathbf{R M S E})=11.6 \% ; \mathrm{n}$ $=82$ treatment means]. In that equation, MPS has a large effect on chewing time, with 160 min more chewing time for forages with MPS $\geq 0.3 \mathrm{~cm}$ and $317 \mathrm{~min}$ more chewing time for long hay compared with finely chopped forage with particle length $<0.3 \mathrm{~cm}$. Ruminating time as a percentage of total chewing time $(59.6 \pm$ $6.4 \%$; mean $\pm \mathrm{SD})$ was predicted $\left(\mathrm{R}^{2}=0.76\right.$; $\mathrm{RMSE}=$ $4.2 \% ; \mathrm{n}=82$ treatment means) from proportion of long hay in the diet, FNDF content, and NDF intake. Byskov et al. (2015) predicted rumination time $(470 \pm 118$ $\min / \mathrm{d} ;$ mean $\pm \mathrm{SD} ; \mathrm{R}^{2}=0.90 ; \mathrm{RMSE}=11.9 \% ; \mathrm{n}=$ 761 cows) from diet composition and DMI but did not consider particle size of the diet. Tafaj et al. (2007) predicted chewing time $\left(694 \pm 14.3 \mathrm{~min} / \mathrm{d}\right.$, mean $\pm \mathrm{SE} ; \mathrm{R}^{2}$ $=0.35 ; \mathrm{RMSE}=17.3 \% ; \mathrm{n}=73$ treatment means) and ruminating time $\left(433 \pm 10.9 \mathrm{~min} / \mathrm{d} ; \mathrm{R}^{2}=0.32 ; \mathrm{RMSE}\right.$ $=89.6 \mathrm{~min} / \mathrm{d} ; \mathrm{n}=73$ treatment means) from forage particle length and FNDF content of the diet. Zebeli et al. (2006) predicted chewing $(691 \pm 11.2 \mathrm{~min} / \mathrm{d}$, mean $\pm \mathrm{SE} ; \mathrm{R}^{2}=0.44 ; \mathrm{RMSE}=76.4 \mathrm{~min} / \mathrm{d} ; 99$ treatment means $)$ and ruminating time $(434 \pm 8.29$, mean $\pm \mathrm{SE}$; $\mathrm{R}^{2}=0.36 ; \mathrm{RMSE}=59.7 \mathrm{~min} / \mathrm{d} ; 99$ treatment means) from peNDF $>1.18$, digestible OM content of forages in the TMR, and NFC content. 
Table 3. Prediction equations for estimating eating, ruminating, and chewing time in dairy cows from dietary characteristics, with particle size expressed on a DM or as-fed (AF) basis ${ }^{1}$

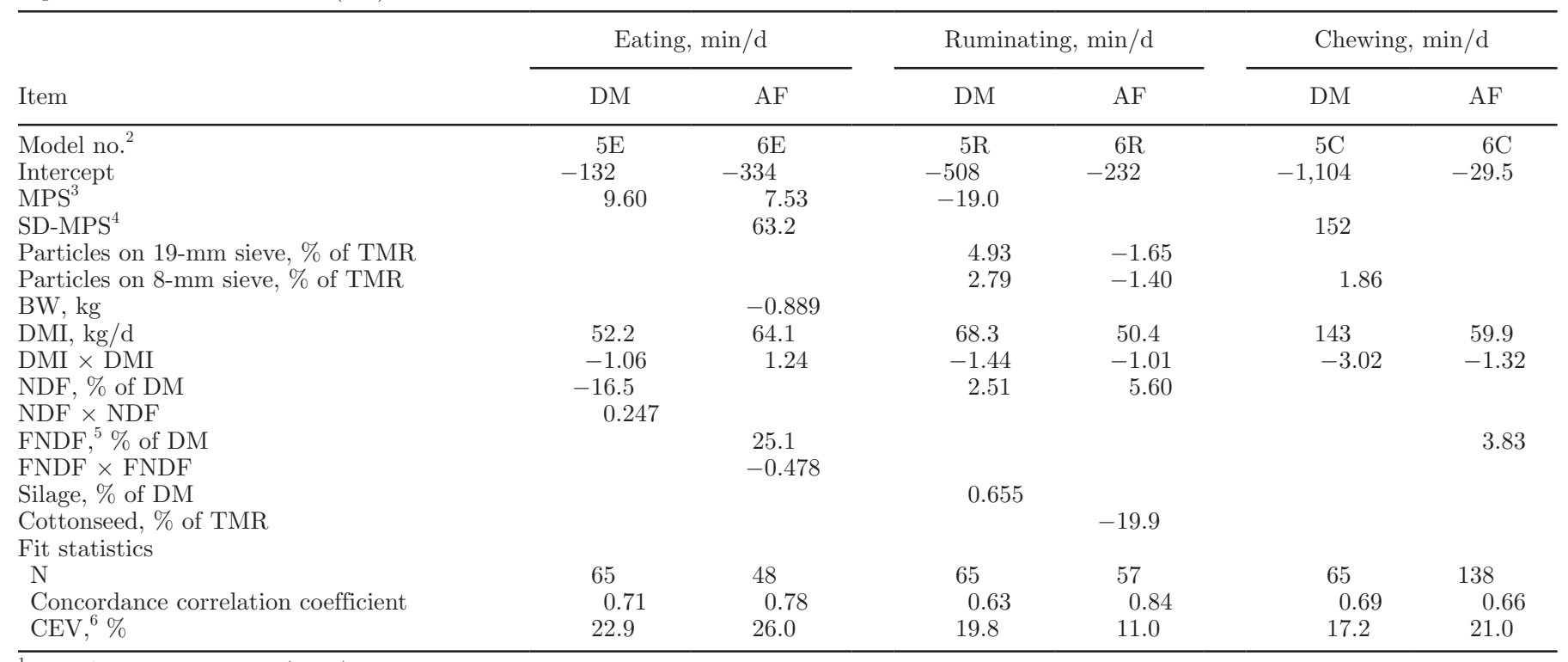

${ }^{1}$ Data from White et al. (2017); used with permission.

${ }^{2}$ Model number as listed by White et al. (2017).

${ }^{3}$ Mean particle size. Calculated assuming a log-normal distribution as described by Waldo et al. (1971) using linear regression of the normal inverse of cumulative proportion of particles retained on 19-, 8-, and (when available) 1.18-mm sieves of the Penn State Particle Separator versus the logarithm (base 10) of screen size, solving for $y=0$.

${ }^{4}$ Standard deviation of MPS. Calculated as the inverse of the slope.

${ }^{5}$ Forage NDF.

${ }^{6}$ Cumulative error variance associated with the prediction equation and residual error, expressed as a percentage of mean eating, ruminating, or chewing time.

More recently, White et al. (2017) developed prediction equations for eating, ruminating, and chewing with improved accuracy and precision based on characteristics of the diet and ruminal digestibility, with particle size expressed on a DM or as-fed basis. The equations that included rumen digestibility variables had similar prediction error as those that included only diet characteristics; thus, the more simple diet-based equations are given in Table 3. The variables retained in the equations were particle size of the TMR (characterized as MPS and proportions of the TMR retained on the 9-mm and 8-mm sieves of a Penn State Particle Separator), BW, DMI, NDF content, FNDF content, proportion of silage (wet forage), and proportion of cottonseed in the TMR. The concordance correlation coefficients (CCC) were moderate (0.63-0.84), and the cumulative error variance associated with the prediction equation and residual error expressed as a percentage of mean eating, ruminating, or chewing time ranged from 11 to $26 \%$, with slightly lower values when particle size was expressed on a DM, rather than as-fed, basis. A main finding in this study was that including representations of peNDF did not improve prediction accuracy beyond including measures of particle size and NDF content separately.

\section{MAIN FUNCTIONS OF CHEWING}

\section{Saliva Secretion and Rumen Buffering}

It is well entrenched in the literature that promoting chewing increases salivary secretion of dairy cows and helps reduce the risk of SARA. However, studies that have quantified the effect of increased chewing time on saliva secretion show that the net increase in salivation per day is rather small. Although it is not possible to directly measure total daily salivary secretion in dairy cows, various studies have measured salivary flow during parts of the day and, together with chewing time, have estimated total secretion with unknown accuracy. Saliva production of dairy cows during resting and eating can be estimated by collecting saliva or swallowed feed, respectively, at the cardia by inserting a collection bag through the rumen fistula.

Across studies with dairy cows consuming TMR (Table 4), mean saliva production while resting averaged $133 \mathrm{~mL} / \mathrm{min}$ (range: 91-156), and saliva production during eating was about 1.6-fold that of resting (mean: $206 \mathrm{~mL} / \mathrm{min}$; range: 192-250). Measuring salivation during rumination is challenging and no estimates are available for high-producing dairy cows; thus, salivary 
secretion during rumination is often assumed to be about the same as during eating. Although salivary flow is increased when cows chew, the total amount of saliva production per day is not greatly affected by chewing time because as time spent chewing increases, time spent resting decreases. Consequently, the increase in saliva produced during chewing is partially offset by a decrease in saliva produced during resting. For example, in the study by Maekawa et al. (2002b), increasing the F:C ratio of the TMR from 40:60 to 60:40 increased total chewing time by $107 \mathrm{~min} / \mathrm{d}$ (14.4\%), but estimated salivary secretion increased by only $25 \mathrm{~L} / \mathrm{d}(11 \%)$. Likewise, in the study by Jiang et al. (2017), increasing the F:C ratio of the TMR from 40:60 to $70: 30$ increased total chewing time by $144 \mathrm{~min} / \mathrm{d}$ (19.8\%), but estimated salivary secretion increased by only $17 \mathrm{~L} / \mathrm{d}(7.3 \%)$.

Salivary secretion per minute of chewing and resting is relatively constant; thus, differences in ensalivation of feed $(\mathrm{mL} / \mathrm{kg}$ of $\mathrm{DM})$ are mainly due to differences in eating rate and the final moisture content of the swallowed bolus. Beauchemin et al. (2008) showed that concentrates were consumed about 3 to 12 times faster than forage (on a DM basis), likely because they required less time for particle size reduction and less lubrication before swallowing. In that study, the moisture content of swallowed masticated concentrates was 50 to $60 \%$ compared with 80 to $90 \%$ for forages. Less saliva was added to concentrates $(1.12-1.19 \mathrm{~mL} / \mathrm{g}$ of $\mathrm{DM})$ compared with forages $(3.40-7.23 \mathrm{~mL} / \mathrm{g}$ of $\mathrm{DM})$ during eating (Beauchemin et al., 2008). When compared on an as-fed basis, salivary secretion during eating was about 3 times greater for hay compared with silage, but there were no differences when compared on a DM basis. Straw promoted twice the amount of saliva as hay or silage on a DM basis because it was consumed more slowly due to its greater NDF content (Beauchemin et al., 2008).

Mixed saliva contains bicarbonate $(125 \mathrm{mEq} / \mathrm{L})$ and phosphate $(26 \mathrm{mEq} / \mathrm{L}$; Bailey and Balch, 1961) and therefore plays an important role in buffering the $\mathrm{pH}$ of the rumen. Bicarbonate neutralizes protons via the carbonic anhydrase reaction producing carbon dioxide and water. Bicarbonate enters the rumen via saliva, during bicarbonate-dependent absorption of VFA and as dietary buffers. Absorption of VFA from the rumen stabilizes ruminal $\mathrm{pH}$ either by removing protons as a result of passive diffusion or by the secretion of bicarbonate due to anion exchange mechanisms. Absorption of VFA in the dissociated state $\left(\mathrm{VFA}^{-}\right)$occurs in exchange for bicarbonate via anion exchangers (Aschenbach et al., 2011). Other minor routes of acid removal from the rumen are passage through the omasal orifice as VFA, ammonia, dihydrogen phosphate, and particulate matter (Allen, 1997).

For a cow producing $250 \mathrm{~L} / \mathrm{d}$ of saliva, the total buffering capacity from saliva has been estimated at $37,750 \mathrm{mEq} / \mathrm{d}(250 \mathrm{~L} \times 151 \mathrm{mEq} / \mathrm{L} ;$ Allen, 1997). The relative amounts of bicarbonate from saliva and VFA absorption depend on the diet. Dijkstra et al. (2012) estimated for dairy cattle fed a high-forage diet that saliva accounted for about half the bicarbonate flow into the rumen, whereas for a high-concentrate diet this was about $35 \%$ (Table 5). Thus, bicarbonate-dependent absorption of VFA represents a greater source of rumen buffering than saliva for most dairy cows. For highconcentrate diets, where subacute rumen acidosis is a concern, incorporating sodium bicarbonate at $1 \%$ of dietary DM would be expected to increase the total bicarbonate flow to the rumen by 3 to $4 \%$. A similar increase in bicarbonate flow into the rumen could be obtained by increasing particle size of the diet or increasing $\mathrm{F}$ : $\mathrm{C}$ ratio of the diet, with a combination of all 3 SARA prevention strategies increasing total bicarbonate flow into the rumen by about $10 \%$ in most cases. Thus, promoting chewing time helps increase the flow of bicarbonate into the rumen, but preventing SARA needs to consider both increasing total buffering of the rumen as well as managing VFA production and absorption from the rumen (Allen, 1997; Aschenbach et al., 2011).

\section{Particle Size Reduction and Microbial Digestion}

Each day, the dairy cow chews about 12,000 to 30,000 times during eating and 20,000 to 40,000 times during rumination (Beauchemin and Buchanan-Smith, 1989; Beauchemin, 1991b; Dado and Allen, 1994), depending on the diet characteristics and the time spent chewing. Dado and Allen (1994) showed that for cows fed a common diet the number of eating and ruminating chews was correlated with eating $(\mathrm{r}=0.90, P<0.001)$ and ruminating $(\mathrm{r}=0.61, P<0.05)$ time.

Mastication during eating and ruminating reduces the particle size of feed and allows the complex fiber matrix to be colonized and digested by rumen microorganisms and indigestible particles to be passed from the rumen, as illustrated in Figure 3. Attachment of rumen microbiota to ingested forage is central for utilization of plant nutrients, and passage of indigestible particles enables the cow to maintain high levels of intake to meet requirements for nutrients.

Mastication during eating performs an initial crude reduction in particle size of the feed, damaging plant tissues and releasing soluble compounds. Extent of particle size reduction during eating is variable and highly 
BEAUCHEMIN

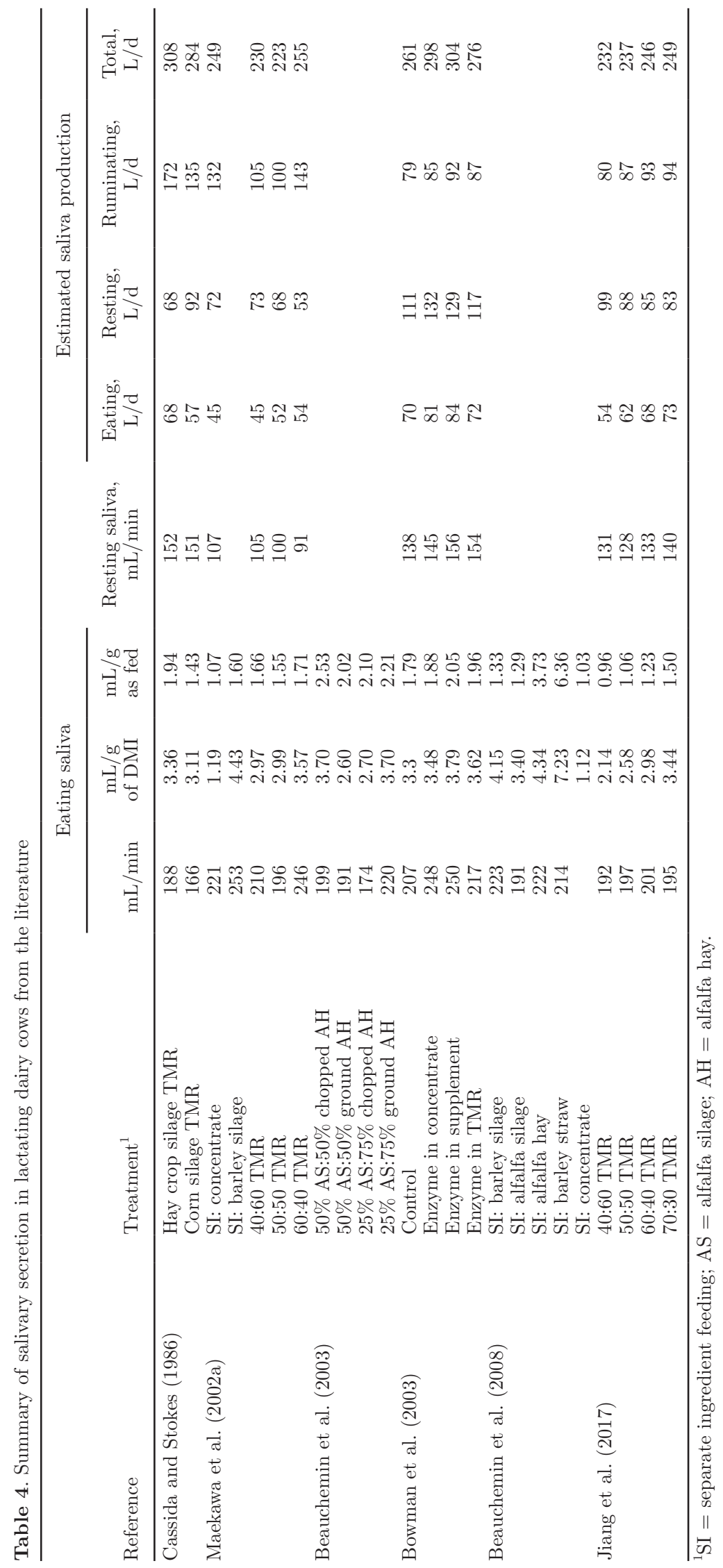


Table 5. Estimated bicarbonate flow into the rumen of dairy cows ${ }^{1}$

\begin{tabular}{lcc}
\hline Item & $\begin{array}{c}\text { Roughage } \\
\text { diet }\end{array}$ & $\begin{array}{c}\text { Concentrate } \\
\text { diet }\end{array}$ \\
\hline Feed intake & 20 & 20 \\
Saliva production, L/d & 250 & 200 \\
VFA production, mol/d & 100 & 120 \\
Total bicarbonate flow, g/d & 4,010 & 4,245 \\
Saliva & $1,875(47 \%)$ & $1,500(35 \%)$ \\
Rumen epithelium & $2,135(53 \%)$ & $2,745(65 \%)$ \\
\hline
\end{tabular}

${ }^{1}$ Source: Dijkstra et al. (2012); used with permission.

dependent on the rate of intake, with less particle reduction occurring as eating rate increases. When eating time is restricted, the resulting longer particle size of swallowed feeds increases the need for rumination (see "Complementarity Between Eating and Ruminating Time"). During eating, larger particles are reduced in size to a greater extent than shorter particles, which accounts for the high correlation coefficient between eating time and particles $\geq 19 \mathrm{~mm}$; however, feed is not reduced to a final uniform particle size before swallowing, as discussed earlier (see "Factors Affecting Eating Behavior").

The damage caused to plant particles during eating creates sites that allow for adhesion of primary bacterial colonizers that begin the process of hydrolyzing the complex structural compounds. Secondary colonizers embed themselves into the extracellular polymeric substances exuded by the primary colonizers within 2 to $4 \mathrm{~h}$ of ingestion (Huws et al., 2013). The biofilm continues to develop as other bacteria are incorporated, fungi penetrate the damaged feed particles, and the consortia progressively degrade the complex and simple carbohydrates. As the material is ruminated, new sites for microbial attachment are created and the extant biofilms on the digesta are disrupted, causing them to be shed and to recolonize new surfaces (Mason and Stuckey, 2016). Chewing during rumination removes the accumulated $\mathrm{CO}_{2}$ and VFA and adds saliva, helping to make the microenvironment at the feed particle surface more favorable to bacterial growth (Mason and Stuckey, 2016). As microbial degradation proceeds the particles weaken and, as particles are ruminated, particle size is further reduced and functional specific gravity is increased.

Thus, rumination - not eating - is the principal means by which feed particles are decreased in size by dairy cattle (Beauchemin, 1991a). This entire process allows undigested plant residues to be eligible to pass from the rumen. Although the importance of rumination for particle size reduction to promote microbial digestion is well recognized, quantitative aspects of time spent ruminating and fiber digestion are not well documented and require further study.

\section{Raft Formation and Particulate Passage from the Rumen}

The ruminal contents are stratified into a liquid phase, a floating mat (raft), and a pool of small particles dispersed within the fluid phase ventrally to the floating mat (Welch, 1982), although these phases are not always distinct in dairy cows fed ad libitum. Newly ingested feed particles, being longer and lighter, tend to contribute to raft formation in the dorsal sac. Ruminal mat formation is thought to enhance the microenvironment needed by the consortium of fibrolytic microorganisms involved in cell wall digestion. It also acts as a filter bed, which helps retain forage particles in the rumen, increasing the time allowed for fiber digestion (Sutherland, 1988). Mat formation strongly depends on intake of FNDF and long particles, the 2 key factors that determine physically effective fiber and chewing time of ruminants (Zebeli et al., 2012). As ingested material is ruminated, particle size is further reduced, particles are hydrated with saliva, entrapped gasses are released, and buoyancy of particles is reduced. As the particles in the raft are reduced in size and specific gravity is increased to the optimum range for passage (Welch, 1982), they tend to sediment ventrally in the rumen, helping to make them suitable for passage from the rumen. This pool of particles is sometimes referred to as escapable (Seo et al., 2009; Figure 4). Chewing plays a key role in increasing the eligibility of particles to pass from the rumen; however, particle size per se is not considered rate limiting for passage. More than half the digesta in the rumen is $<0.3 \mathrm{~mm}$ (mesh size) and therefore potentially escapable (Gasa et al., 1991). To exit the rumen the small particles need to be near the omasal orifice. Muscular contractions of the rumen push the digesta that is eligible for passage toward the reticulum and eventually through the omasal orifice and into the omasum (Ruckebusch, 1988).

\section{Rumen Motility}

The muscular activity of the reticulorumen is a combination of primary (mixing cycle) and secondary (eructative) contractions (Ruckebusch, 1988). The number and strength of the contractions are increased significantly during eating and ruminating activity (Egert et al., 2014; Nogami et al., 2017). In contrast, contractions are inhibited during bloat and deprivation of food or water. Contractions tend to be smaller when animals are fed a diet of concentrates, and rumen motility is reduced or nonexistent in animals experiencing acidosis (Huber, 1976). Thus, chewing promotes strong, regular mixing contractions that help move swallowed boli from the cardial area of the reticulorumen where 


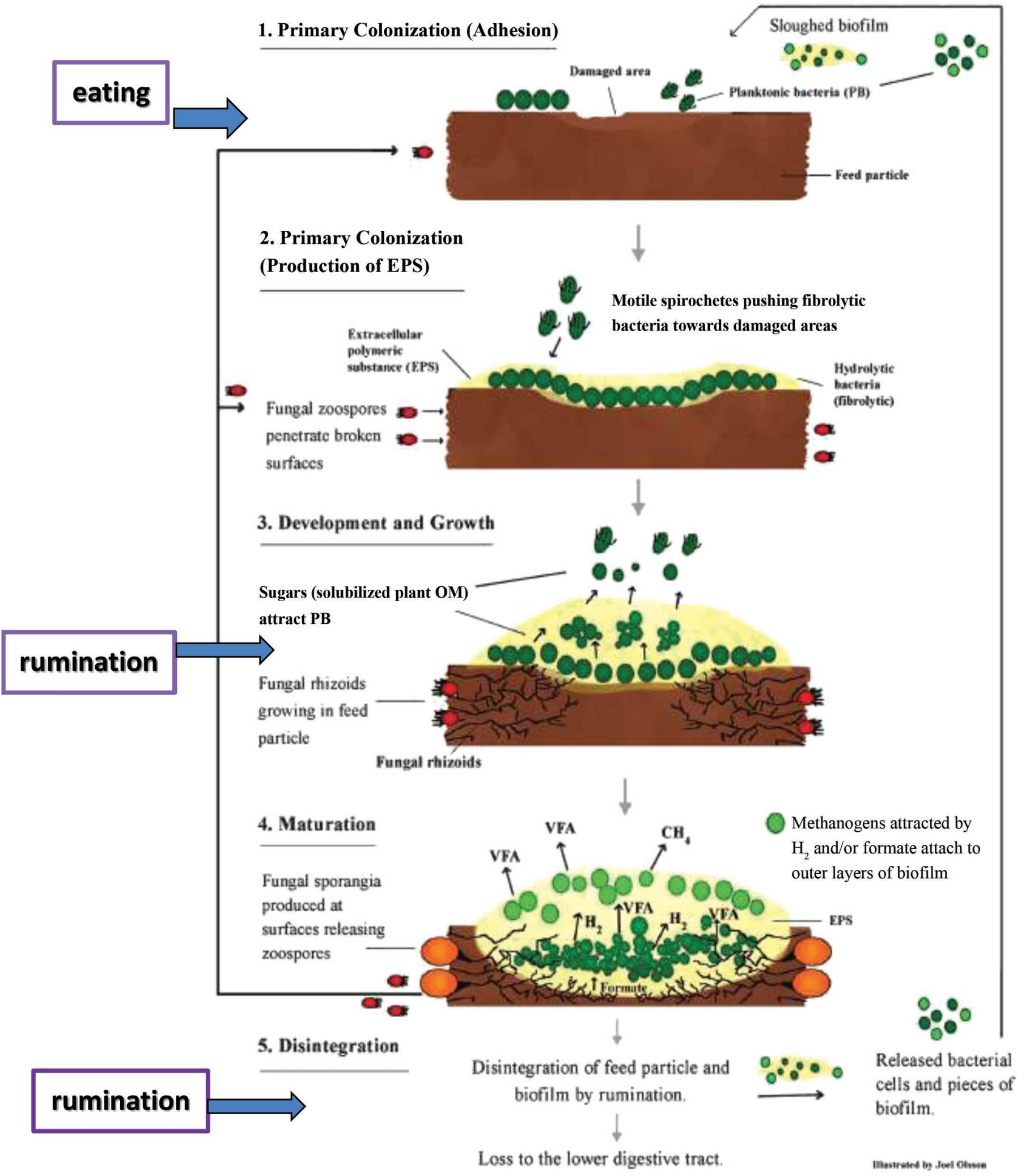

Figure 3. Visual representation of the importance of rumination for microbial digestion of feed particles. Adapted from Leng (2014), with permission from CSIRO Publishing. Color version available online. 
the feed enters the rumen into the other compartments of the rumen. The contractions cause continuous movement of digesta within the rumen, helping to position the end products of digestion near the epithelium for absorption and, likewise, moving secretions of bicarbonate from the epithelium into the ruminal contents. Contractions of the reticulorumen are also essential for eructation of gas from the rumen. Finally, contractions move the particles from the inescapable to escapable pool as discussed above and help propel fluid, soluble compounds, microbial cells, and undigested feed residues into the omasum. An increase in frequency and strength (duration, amplitude) of contractions can increase passage rate of these compounds from the rumen (Okine et al., 1989).

\section{Saliva, Liquid Passage, and Site of Starch Digestion}

Increasing the $\mathrm{F}: \mathrm{C}$ ratio, and sometimes particle size, of the diet tends to increase fractional passage rate of liquid (i.e., proportion of liquid that leaves the rumen per unit time; Krause et al., 2002a; Cao et al., 2010) due to increased salivation and motility. Due to size and specific gravity, passage of grain particles is af- fected by liquid dilution rate, especially if grains are finely processed. Rate of digestion and the rate of passage are competitive processes; thus, a faster liquid passage rate and removal of small particles from the rumen decreases ruminal digestion of starch. With increased $\mathrm{F}: \mathrm{C}$ ratio, and to a lesser extent increasing particle size of diets, the site of starch digestion can be shifted such that the proportion of starch digested in the intestine increases (Yang et al., 2001a; Yang and Beauchemin, 2006). The shift in site of starch digestion can be a major contributing factor for the reduced risk of acidosis with increased intake of physically effective fiber.

In addition to shifting the site of digestion of starch, increasing FNDF content of the diet decreases starch intake and rate of VFA production in the rumen, which also help to minimize postprandial reduction in rumen $\mathrm{pH}$. Furthermore, an increase in fractional liquid passage would increase fractional rates of VFA passage and decrease VFA accumulation in the rumen. In the study by Yang et al. (2001a), increasing F:C from 35:65 to $55: 45$ decreased starch intake by $2 \mathrm{~kg} / \mathrm{d}$, the proportion of starch digested in the rumen was reduced by $20 \%$, and the proportion digested in the intestine increased by $20 \%$. Increasing the chop length of silage

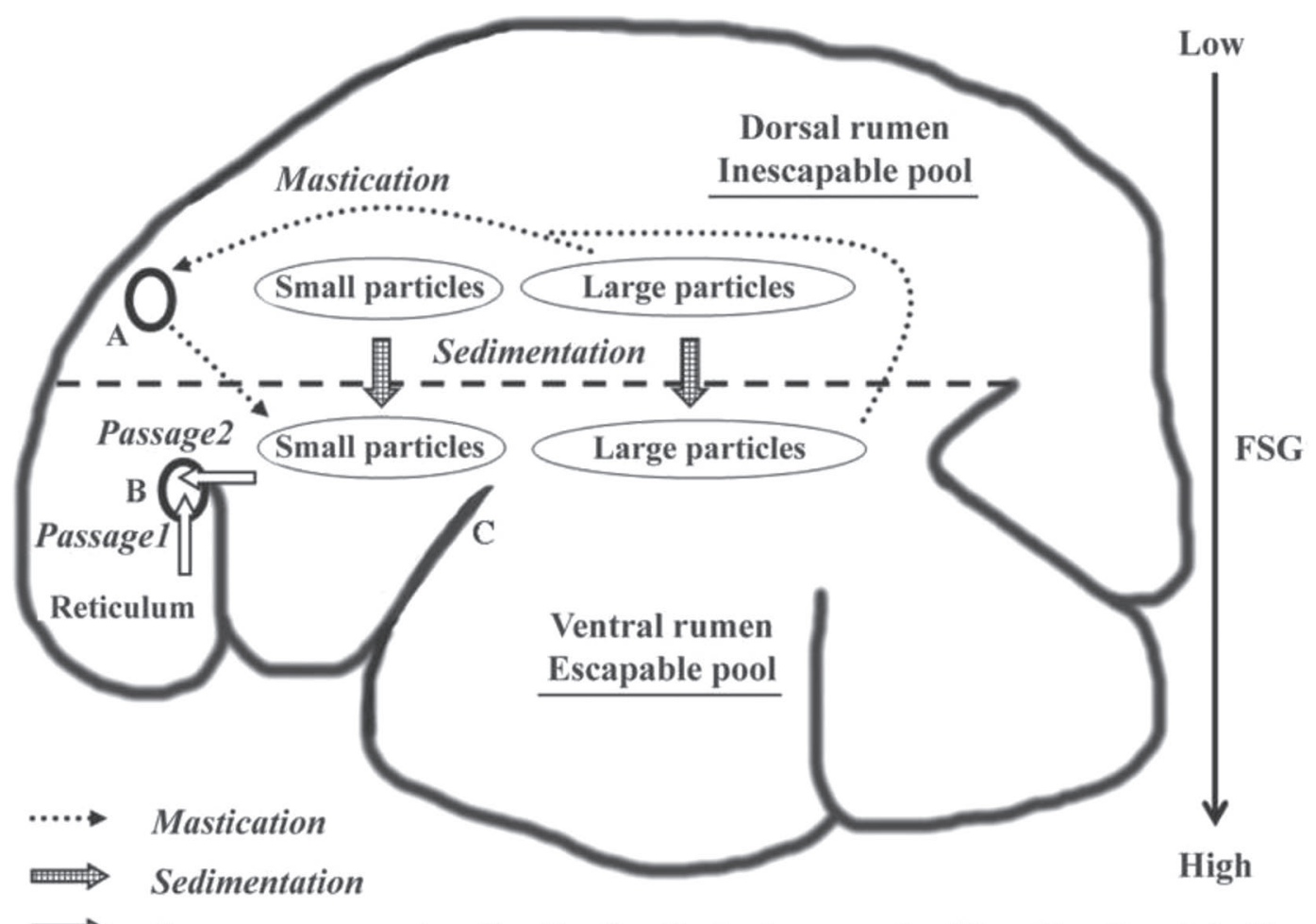

Figure 4. Conceptual diagram of feed particles in the rumen. Long and buoyant newly ingested particles form a raft in the dorsal sac, which is defined as the inescapable pool. As particles are digested and ruminated, particle size is increased and particles become less buoyant, allowing the particles to sink ventrally into the escapable pool. Muscular contractions of the rumen move the sedimented digesta toward the reticulum and eventually through the omasal orifice. FSG = functional specific gravity. Source: Seo et al. (2009); reproduced with permission. 
also increased the proportion of starch digested in the intestine (\% of intake) by about $20 \%$, but starch intake was not affected. Similar effects were reported by Yang and Beauchemin (2006). In those 2 studies (Yang et al., 2001a; Yang and Beauchemin, 2006), effects on site of NDF digestibility were minimal because the rate of passage of long particles from the rumen is limited by particle size reduction, specific gravity, motility of the rumen, and other factors, as discussed previously (see "Raft Formation and Particulate Passage from the Rumen"). Although a change in the site of digestion of starch is not a direct function of chewing time, it is affected by factors that affect chewing (physically effective fiber intake).

\section{RUMINATION MONITORING ON FARM TO ASSESS COW HEALTH}

\section{Measuring Chewing Time}

Eating and ruminating behaviors of cattle have traditionally been monitored in small-scale research studies by visual observation, video recording of cows, or recording jaw movements. However, these methods are not practical for loose-housed cattle, larger scale studies, or commercial dairy farms. Visual observation is both labor intensive and time consuming and requires trained personnel to observe activity of individual cows at a predetermined interval (e.g., every 5 min for 1-2 d; Krause et al., 2002b; Beauchemin et al., 2003; Zhang et al., 2010; Alamouti et al., 2014). Another approach has been to monitor the activity of a pen of animals by recording the total number of animals performing each activity (e.g., Overton et al., 2002). Video recordings are also time consuming because the scanning interval needs to be frequent such that accuracy of the estimates is not compromised (Hämäläinen et al., 2016). Dong et al. (2018) recommended a minimum observational frequency of $2 \mathrm{~d}$ with 4 -min intervals for eating time and $3 \mathrm{~d}$ with 4-min intervals for ruminating time. Bhandari et al. (2008) reported a correlation coefficient of 0.94 between continuous monitoring and 5 -min scan sampling of eating and ruminating behavior when observed over 3 d. Hämäläinen et al. (2016) recommended a sampling interval of 4 min for eating activity and 15 min for ruminating.

Jaw movements of cattle can be accurately measured using various sensors (Beauchemin et al., 1989; Kononoff et al., 2002; Watt et al., 2015), with the outputs recorded manually or summarized using software to interpret the signal to determine eating and rumination activity. In recent years, several sensors have been developed that can be used to record chewing activity of dairy cows in commercial facilities (Table 6). Some systems use an accelerometer mounted on an ear tag (e.g., CowManager SensOor, Agis Automatisering BV, Harmelen, the Netherlands; Smartbow, Smartbow GmbH, Jutodasse, Austria) or neck collar (e.g., MooMonitor+, DairyMaster, Causeway, Co. Kerry, Ireland; eating only: CowScout Neck, GEA, Zurich, Switzerland) to detect movement. Others use a microphone mounted on a collar to detect sound (e.g., Hi-Tag, Heatime, HR-tag, Sense-Time; SCR Engineers Ltd., Netanya, Israel). These systems provide the operator with a rapid assessment and do not disrupt the natural behavior of the animal.

The precision and accuracy of some of these systems have been evaluated in various studies. Using accelerometer sensors, Borchers et al. (2016) reported that with CowManager eating times were correlated with visual behavior $(\mathrm{r}=0.88$; $\mathrm{CCC}=0.82)$, but ruminating times were only moderately correlated with visual observations $(\mathrm{r}=0.69 ; \mathrm{CCC}=0.59)$. In the same study, Smartbow rumination times $(\mathrm{r}=0.97$; $\mathrm{CCC}=$ 0.96) corresponded well to visual results. Much higher agreement for rumination $(\mathrm{r}=0.93$; $\mathrm{CCC}=0.93)$ was reported by Bikker et al. (2014) for CowManager compared with visual observation, although the relationship for eating time was slightly less $(\mathrm{r}=0.88$; $\mathrm{CCC}=$ 0.75 ). Lower agreement for eating time between sensor and human observation can be anticipated because the definition of eating can vary substantially.

Schirmann et al. (2009) reported that rumination times from the Hi-Tag acoustic system were highly correlated with those from direct observation $(\mathrm{r}=0.93$, $\left.\mathrm{R}^{2}=0.87\right)$. Ambriz-Vilchis et al. (2015) evaluated the acoustic system against video recordings for lactating dairy cows and concluded that the 2 methods were highly correlated (overall mean slope not different from 1 ), but there was substantial variation among individual cows $\left(\mathrm{R}^{2}=0.28-0.98\right.$; slopes from 0.74 to 1.43$)$. With neck-mounted acoustic sensors, there can be variations due to neck muscle or thick skin that interferes with placement and function of the sensor and interference by background sounds, which can limit their use (Goldhawk et al., 2013). For example, Ambriz-Vilchis et al. (2015) observed very poor performance of Heatime neck collars when used on grazing dairy cows in contrast to when used on housed dairy cows, and Goldhawk et al. (2013) reported that the system failed to work properly for beef cattle.

Furthermore, there can be substantial differences between rumination times estimated with acoustic neck tags versus accelerometer ear tags. In a study that used both types of sensors, Dolecheck et al. (2015) reported that rumination times from Hi-Tag neck sensors were on average $39 \%$ greater than those from CowManager ear tag sensors (551 vs. $396 \mathrm{~min} / \mathrm{d}, \mathrm{n}=18$ cows). As 
INVITED REVIEW: EATING AND RUMINATION ACTIVITY IN DAIRY COWS

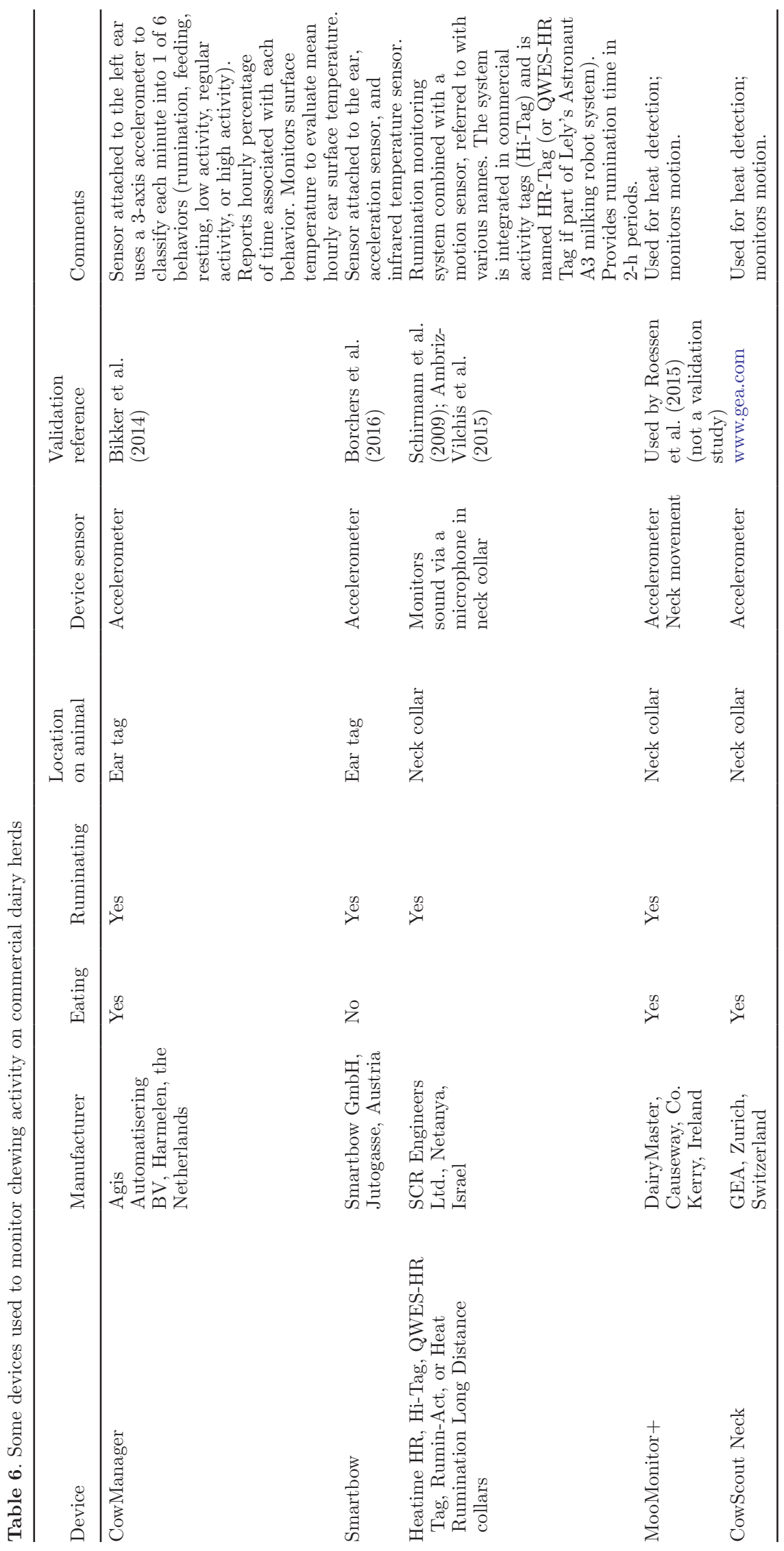

Journal of Dairy Science Vol. 101 No. 6, 2018 
mean rumination time in dairy cows is about $435 \mathrm{~min} / \mathrm{d}$ (Table 1), it is not clear which sensor best represented actual rumination time.

Overall, sensor technologies provide a low-cost and convenient method of monitoring chewing behavior in freestall-housed commercial dairy cows, but accuracy and precision can be somewhat variable depending on the sensor and conditions of use. Given the lack of better alternatives, it is recommended that these monitoring devices be used on commercial dairy farms, but the data should be interpreted with caution, especially when combined across farms. Although the actual number of minutes of eating and ruminating per day using these systems may be associated with error, the relative changes in behaviors of individual cows over time can be useful for detecting cows that are off-feed, sick, in estrus, experiencing acidosis, and so forth. Some potential ways in which rumination activity can be used in management decisions on farm are described in the following sections.

\section{Assessment of Ruminal Acidosis Risk}

Cows experiencing rumen acidosis ruminate less than healthy cows. DeVries et al. (2009) reported that rumination time in dairy cows was decreased on $\mathrm{d} 1$ following an acidosis challenge by more than $1.5 \mathrm{~h}$ compared with baseline despite increased feeding activity and similar DMI. Because cows experiencing acidosis ruminate less than healthy cows, the percentage of cows ruminating within a herd at any given time between management events (feeding, milking) is often considered by dairy advisors as an indicator of herd rumen health. Maekawa et al. (2002a) reported that on average, 39\% of cows fed a TMR were ruminating at any one time when observed during the daytime between feedings (1000 to $1500 \mathrm{~h}$ ) or during the nighttime (1900 to 0700 h). When ingredients were offered separately, a lower proportion of the cows were ruminating during the day (35\%) compared with during the night (47\%) because rumination activity was greatest in the nighttime hours. To determine whether the proportion of cows ruminating within a herd at a particular time could be a useful tool for evaluating risk of acidosis, DeVries et al. (2009) video recorded behavior of 8 dairy cows before and after induction of acidosis in 3 consecutive 14-d challenge periods. They calculated the proportion of cows ruminating between daytime management events (feeding, milking). Of the cows deemed to be more susceptible to acidosis (based on rumen $\mathrm{pH}$ ), $42.6 \pm 18.1 \%$ (mean \pm $\mathrm{SD}$ ) were ruminating during the baseline period compared with only $32.2 \pm 18.3 \%$ ruminating during the acidosis challenge period. For the low-risk cows, 46.5 $\pm 15.3 \%$ were ruminating during the baseline period compared with $40.0 \pm 16.7 \%$ ruminating during the acidosis challenge day. From these studies, it can be concluded that about $40 \%$ or more of healthy cows are likely to be ruminating between management events. The proportion of cows ruminating may be lower if ruminal acidosis is prevalent in a herd, but detecting ruminal acidosis via visual observation would be laborious. Hence, automation of rumination monitoring may be a useful means of detecting differences in rumination. For example, in the study of DeVries et al. (2009), to detect the lower proportion of high-risk cows ruminating after the acidosis challenge the percentage of cows ruminating would have had to be observed on, and averaged over, 48 individual minutes to determine whether the percentage truly varied from baseline.

Another benchmark that may be useful on farm to access rumen acidosis is the duration of the latency period between eating and the onset of rumination. For the healthy commercial dairy cow, rumination normally occurs between feeding events, but when diets with high soluble fraction are fed, rumination activity after meals can be delayed despite a large quantity of feed in the rumen (Welch, 1982). Thus, it might be possible to use the length of this latency period as an indication of risk of acidosis. In a study of nonlactating heifers fed diets of 70:30 or 30:70 F:C ratio (DM basis), a mean latency period of $19.4 \mathrm{~min}$ (range: 4.1-44.5) and 26.0 min (6.0-70.6), respectively, was observed (Dong et al., 2018). The mean rumen $\mathrm{pH}$ of cows in that study was 6.57 and 6.15 , respectively.

\section{Estrus Detection}

In recent years, there has been interest in determining whether automated technologies, including rumination measurements, could be used to supplement or replace visual detection of estrus. Pahl et al. (2015) reported for 25 primiparous and 37 multiparous cows a decline in eating time and rumination time on the day before and the day of insemination compared with the baseline days. Differences were greatest on the day before insemination, which would suggest that this information could be used to help improve timely insemination. Reith and Hoy (2012) explored the relationship between rumination time and estrus (265 cycles) in 224 cows on 4 farms. On the day of estrus, cows ruminated $17 \%$ (74 $\mathrm{min} / \mathrm{d}$ ) less than during the baseline period on average. However, substantial variation was observed among cows, with the decrease ranging between -71 and $+16 \%$. The decrease was more pronounced in primiparous than in mature cows. In a follow-up study, Reith et al. (2014) examined behavior of dairy cows (453 estrous cycles) over the periestrous period and reported that daily rumination time was reduced on average by $19.6 \%$ 
$(83 \mathrm{~min} / \mathrm{d})$, with $86.2 \%$ of all cows showing decreased rumination time compared with $76.5 \%$ of cows with increased activity. Greatest cow activity and lowest rumination time occurred between 0200 and $0800 \mathrm{~h}$ and 0400 and $1000 \mathrm{~h}$ on the day of estrus, respectively. In a study of 32 Holstein cows, several different automated monitoring technologies were used to monitor chewing activity, temperature, and activity before and during estrus (Dolecheck et al., 2015). Eighteen cows displayed estrus (standing to be mounted) during the study. The sensors detected increased physical activity, feeding time, and ruminal temperate and decreased lying time and rumination (40\% less) during estrus compared with the $14 \mathrm{~d}$ before estrus. Based on these studies, it would seem that rumination time, when used in combination with other assessments, can be useful for detecting estrus in dairy cows.

\section{Detection of Parturition and IIIness in Dairy Cows}

Rumination time, alone or when combined with other variables, has been investigated as a means of detecting parturition and illness in dairy cows on commercial farms (Rutten et al., 2013; Pahl et al., 2014). As normal daily variation in ruminating time is about $10 \%$ ( $>10 \%$ with finely chopped or high-grain diets; Dulphy et al., 1979), the assumption is that large reductions in rumination time by an individual cow on a particular day can be an indication of a change in cow health. For example, rumination time has been shown to be consistently reduced about $8 \mathrm{~h}$ before calving and increase about $6 \mathrm{~h}$ later, likely a result of limited feed intake (Schirmann et al., 2013; Pahl et al., 2014; Paudyal et al., 2016; Borchers et al., 2017; Kovács et al., 2017). Thus, monitoring rumination time could be useful in predicting time of calving.

Studies have also examined whether rumination activity is consistently lower in sick compared with healthy cows. The difference in rumination time between sick and healthy cows appears to depend on the disease, the period relative to calving, and the season (Paudyal et al., 2016). Accounting for DIM and parity, King et al. (2017) reported (13 mo study) that daily rumination time (using the Hi-Tag system) declined by $45 \mathrm{~min} / \mathrm{d}$ (10-20\%) from d 8 before a diagnosis of displaced abomasum $(\mathrm{n}=5)$, by $25 \mathrm{~min} / \mathrm{d}(5-6 \%)$ from $6 \mathrm{~d}$ before subclinical ketosis $(\mathrm{n}=19)$, and by $50 \mathrm{~min} / \mathrm{d}(9-13 \%)$ from $5 \mathrm{~d}$ before pneumonia $(\mathrm{n}=7)$. Kaufman et al. (2016) monitored rumination activity (Hi-Tag system) of dairy cows on 4 commercial farms from $14 \mathrm{~d}$ before until $28 \mathrm{~d}$ after calving and reported that multiparous cows with ketosis but without other health problems $(\mathrm{n}=76)$ ruminated $25 \pm 12.8 \mathrm{~min} / \mathrm{d}$ less than healthy $(\mathrm{n}=87)$ multiparous cows, whereas those with ketosis and other health problems $(\mathrm{n}=39)$ ruminated $44 \pm$ $15.6 \mathrm{~min} / \mathrm{d}$ less than healthy cows. In that study, primiparous cows showed no change in rumination time in relation to incidence of ketosis, possibly due to the limited numbers of primiparous cows with ketosis $(\mathrm{n}=$ 14). Schirmann et al. (2016) found that compared with healthy cows $(\mathrm{n}=20)$, those with subclinical ketosis $(\mathrm{n}=9)$ and ketosis plus metritis $(\mathrm{n}=9)$ had lower prepartum DMI and continued to eat less for 2 to 3 wk postpartum, but rumination was decreased only in cows with ketosis precalving.

Liboreiro et al. (2015) monitored cows $(\mathrm{n}=296)$ for $\pm 17 \mathrm{~d}$ relative to parturition and examined the relationship between rumination and illness (occurrence of twins and stillborn calves, subclinical hypocalcemia, metritis, retained fetal membranes, and subclinical ketosis). Cows that delivered twins ruminated less postpartum compared with cows that delivered a single calf, whereas cows that delivered stillborn calves ruminated less precalving than cows that delivered healthy calves. Subclinical hypocalcemia and ketosis did not affect rumination time, but cows with retained fetal membranes or metritis ruminated less than healthy cows from wk 3 to 9 postpartum. Stangaferro et al. (2016c) showed that rumination time combined with cow activity was effective for identifying cows with severe cases of metritis but less effective for identifying cows with mild cases of metritis. Kovács et al. (2017) reported less rumination time $8 \mathrm{~h}$ before calving up until $4 \mathrm{~d}$ postpartum for cows with dystocia compared with cows that had a normal calving.

Stangaferro et al. (2016b) showed that monitoring rumination time in combination with cow activity was effective for identifying cows with clinical cases of mastitis caused by Escherichia coli but not when it was caused by other pathogens. Not all cows that developed a case of mastitis were detected based on a change in activity. Both Siivonen et al. (2011) and Fitzpatrick et al. (2013) observed that, after experimentally inducing mastitis using endotoxin, cows ruminated less in the following hours, indicating that a decrease in rumination activity may be a good indicator of some types of discomfort. However, rumination time was not associated with the discomfort caused by lameness (Walker et al., 2008).

Paudyal et al. (2016) monitored rumination time (Heatime HR) in 210 multiparous Holstein cows \pm 14 d relative to parturition during hot and cool seasons to determine whether illness detection was affected by ambient environment. Cows affected by severe negative energy balance and subclinical ketosis that calved in the hot season ruminated less both pre- and postpartum. The authors also observed that dystocia during the hot season was associated with less rumination prepartum, 
whereas during the cool season it resulted in less rumination postpartum. For cows with ketosis, rumination time was reduced both pre- and postpartum in both seasons. Paudyal et al. (2016) also reported that for cows with hypocalcemia and mastitis, rumination time was reduced postpartum when cows calved during the cool season, and cows with metritis ruminated less in both seasons.

Stangaferro et al. (2016a) used rumination time and physical activity to score the health of cows $(\mathrm{n}=1,121$; 451 nulliparous and 670 multiparous) monitored from $21 \mathrm{~d}$ before expected calving until $80 \mathrm{~d}$ after calving. Rumination time, physical activity, and health scores of cows were lower from -5 to $5 \mathrm{~d}$ after clinical diagnosis depending on the disorder and parameter compared with healthy cows.

With the development of sensor technology, rumination time of individual animals is now simple to monitor on commercial farms. Taken together, these studies indicate that reduced rumination time can be correlated with parturition and the manifestation of some illnesses. However, because a decrease in rumination time does not confirm the occurrence of disease or indicate the type of disease, the challenge for dairy managers is using the information in real time to detect the disease early or even prevent the disease from occurring. As monitoring rumination time is easier than monitoring DMI, it can be a useful on-farm tool for detecting health problems. Monitoring changes in rumination activity using sensors provides additional insights into overall cow health and is best used to complement traditional methods of illness detection in dairy cows.

\section{Heat Stress}

Abeni and Galli (2017) explored use of cow activity and rumination time as an indication of heat stress using 58 dairy cows during 2 extreme periods of the summer (no heat stress vs. high heat stress) where temperature-humidity index (THI; 68 vs. 90) differed. During heat stress, total rumination time decreased by about $35 \%$, with the greatest decrease in rumination occurring during the afternoon when temperature was hottest. Those results confirm a previous study by Soriani et al. (2013) that reported a negative relationship between rumination time and daily maximum THI $(\mathrm{r}=$ -0.32 ) when THI exceeded 76 as well as a shift toward greater proportion of rumination during the nighttime. However, a recent study by Stone et al. (2017) showed no relationship between rumination time and maximum THI (ranging from about 40 to 85). Paudyal et al. (2016) observed that rumination time in healthy cows at $-14 \mathrm{~d}$ relative to parturition was shorter in the hot season (monthly average THI $\geq 76$ ) than in the cool season (monthly average THI $<76 ; 432$ vs. $487 \mathrm{~min} / \mathrm{d}$ ). Postpartum, the effects of hot weather on rumination time depended on the health of the cow. During heat stress, cows in negative energy balance or with subclinical ketosis during early lactation ruminated less than healthy cows.

\section{Methane Production}

Recent focus on reducing greenhouse gas production from ruminant systems has spurred interest in developing accurate and inexpensive proxies (i.e., indicators) for use on farm to assess methane production from individual cows (Negussie et al., 2017). The potential of using rumination time as a proxy for methane production was examined by Watt et al. (2015) for cows in a pasture-based automatic milking system. Rumination activity was monitored acoustically for 156 dairy cows, and methane emissions of individual cows were monitored using the head chamber GreenFeed system (CLock, Rapid City, SD). Older cows that were heavier had greater DMI, ruminated longer, and produced more methane compared with younger cows. Estimated DMI had direct positive effects on rumination and methane production, but there was no independent direct effect of rumination on methane production. The study concluded that monitoring rumination time had no direct value as a single proxy for estimating methane production.

\section{CONCLUSIONS}

The review evaluates past and recent information on chewing behavior of dairy cows. Eating time and ruminating time are affected by both chemical and physical characteristics of the diet, but other factors such as feeding management, cow variability, and health can have equally large effects on chewing time. These effects are not considered in prediction equations of chewing time. Chewing is critical for promoting salivation, particle size reduction, microbial digestion, and passage of undigested material from the rumen, but the effect of a change in chewing time on these functions is difficult to quantify. Recently developed low-cost sensors that monitor chewing activity of dairy cows in commercial facilities can provide information that can be helpful in management decisions, especially when combined with other criteria.

\section{ACKNOWLEDGMENTS}

Special thanks to R. White (Virginia Tech University, Blacksburg) for providing unpublished data from a 
meta-analysis on factors affecting eating and ruminating time in dairy cows.

\section{REFERENCES}

Abeni, F., and A. Galli. 2017. Monitoring cow activity and rumination time for an early detection of heat stress in dairy cow. Int. J. Biometeorol. 61:417-425. https://doi.org/10.1007/s00484-016-1222-z.

Aikman, P. C., C. K. Reynolds, and D. E. Beever. 2008. Diet digestibility, rate of passage, and eating and rumination behavior of Jersey and Holstein cows. J. Dairy Sci. 91:1103-1114. https://doi .org/10.3168/jds.2007-0724.

Akbari-Afjani, A., A. Zali, M. Gangkhanlou, M. Dehghan-Banadaky, S. M. Nasrollahi, and W. Z. Yang. 2014. Dietary ratios of maize silage to lucerne hay affect feed intake, chewing activity and milk production of dairy cows. Anim. Prod. Sci. 54:263-269. https://doi .org/10.1071/AN12214.

Alamouti, A. A., M. Alikhani, G. R. Ghorbani, A. Teimouri-Yansari, and M. Bagheri. 2014. Response of early lactation Holstein cows to partial replacement of neutral detergent soluble fibre for starch in diets varying in forage particle size. Livest. Sci. 160:60-68. https:// doi.org/10.1016/j.livsci.2013.12.009.

Alamouti, A. A., M. Alikhani, G. R. Ghorbani, and Q. Zebeli. 2009. Effects of inclusion of neutral detergent soluble fibre sources in diets varying in forage particle size on feed intake, digestive processes, and performance of mid-lactation Holstein cows. Anim. Feed Sci. Technol. 154:9-23. https://doi.org/10.1016/j.anifeedsci 2009.07.002.

Albright, J. L. 1993. Feeding behavior of dairy cattle. J. Dairy Sci. 76:485-498. https://doi.org/10.3168/jds.S0022-0302(93)77369-5.

Allen, M. S. 1997. Relationship between fermentation acid production in the rumen and the requirement for physically effective fiber. J. Dairy Sci. 80:1447-1462. https://doi.org/10.3168/jds.S0022 $-0302(97) 76074-0$

Ambriz-Vilchis, V., N. S. Jessop, R. H. Fawcett, D. J. Shaw, and A. I. Macrae. 2015. Comparison of rumination activity measured using rumination collars against direct visual observations and analysis of video recordings of dairy cows in commercial farm environments. J. Dairy Sci. 98:1750-1758. https://doi.org/10.3168/jds 2014-8565.

ANSI (American National Standards Institute). 1998. Method of determining and expressing particle size of chopped forage materials by screening. ANSI/ASAE S424.1:562-564. ANSI, Washington, DC.

ASABE (American Society of Agricultural and Biological Engineers). 2007. Method of determining and expressing particle size of chopped forage materials by screening. ANSI/ASAE S424.1:663665. ASABE, St. Joseph, MI.

Aschenbach, J. R., G. B. Penner, F. Stumpff, and G. Gäbel. 2011. Ruminant nutrition symposium: Role of fermentation acid absorption in the regulation of ruminal pH. J. Anim. Sci. 89:1092-1107. https://doi.org/10.2527/jas.2010-3301.

Ash, R. W., and R. N. Kay. 1959. Stimulation and inhibition of reticulum contractions, rumination and parotid secretion from the forestomach of conscious sheep. J. Physiol. 149:43-57.

Bailey, C. B. 1961. Saliva secretion and its relation to feeding in cattle. 3 . The rate of secretion of mixed saliva in the cow during eating, with an estimate of the magnitude of the total daily secretion of mixed saliva. Br. J. Nutr. 15:443-451.

Bailey, C. B., and C. C. Balch. 1961. Saliva secretion and its relation to feeding in cattle. 2. The composition and rate of secretion of mixed saliva in the cow during rest. Br. J. Nutr. 15:383-402.

Beauchemin, K. A., and L. Rode. 1994. Compressed baled alfalfa hay for primiparous and multiparous dairy cows. J. Dairy Sci. 77:10031012. https://doi.org/10.3168/jds.S0022-0302(94)77036-3.

Beauchemin, K. A., and L. Rode. 1997. Minimum versus optimum concentrations of fiber in dairy cow diets based on barley silage and concentrates of barley or corn. J. Dairy Sci. 80:1629-1639. https://doi.org/10.3168/jds.S0022-0302(97)76094-6.
Beauchemin, K. A. 1991a. Ingestion and mastication of feed by dairy cattle. Pages 439-463 in The Veterinary Clinics of North America: Dairy Nutrition Management. C. J. Sniffen and T. H. Herdt, ed. Saunders, Philadelphia, PA.

Beauchemin, K. A. 1991b. Effects of dietary neutral detergent fiber concentration and alfalfa hay quality on chewing, rumen function, and milk production of dairy cows. J. Dairy Sci. 74:3140-3151. https://doi.org/10.3168/jds.S0022-0302(91)78499-3.

Beauchemin, K. A., and J. G. Buchanan-Smith. 1989. Effects of dietary neutral detergent fiber concentration and supplementary long hay on chewing activities and milk production of dairy cows. J. Dairy Sci. 72:2288-2300. https://doi.org/10.3168/jds.S0022 $-0302(89) 79360-7$

Beauchemin, K. A., L. Eriksen, P. Nørgaard, and L. M. Rode. 2008. Short communication: Salivary secretion during meals in lactating dairy cattle. J. Dairy Sci. 91:2077-2081. https://doi.org/10.3168/ jds.2007-0726.

Beauchemin, K. A., W. Z. Yang, and L. M. Rode. 2003. Effects of particle size of alfalfa-based dairy cow diets on chewing activity, ruminal fermentation and milk production. J. Dairy Sci. 86:630-643. https://doi.org/10.3168/jds.S0022-0302(03)73641-8.

Beauchemin, K. A., S. Zelin, D. Genner, and J. G. Buchanan-Smith. 1989. An automatic system for quantification of eating and ruminating activities of dairy cattle housed in stalls. J. Dairy Sci. 72:2746-2759. https://doi.org/10.3168/jds.S0022-0302(89)79418 -2 .

Bhandari, S. K., S. Li, K. H. Ominski, K. M. Wittenberg, and J. C Plaizier. 2008. Effects of the chop lengths of alfalfa silage and oat silage on feed intake, milk production, feeding behavior, and rumen fermentation of dairy cows. J. Dairy Sci. 91:1942-1958. https://doi.org/10.3168/jds.2007-0358.

Bikker, J. P., H. van Laar, P. Rump, J. Doorenbos, K. van Meurs, G. M. Griffioen, and J. Dijkstra. 2014. Technical note: Evaluation of an ear-attached movement sensor to record cow feeding behavior and activity. J. Dairy Sci. 97:2974-2979. https://doi.org/10.3168/ jds.2013-7560.

Borchers, M. R., Y. M. Chang, K. L. Proudfoot, B. A. Wadsworth, A. E. Stone, and J. M. Bewley. 2017. Machine-learning-based calving prediction from activity, lying, and ruminating behaviors in dairy cattle. J. Dairy Sci. 100:5664-5674. https://doi.org/10.3168/jds .2016-11526.

Borchers, M. R., Y. M. Chang, I. C. Tsai, B. A. Wadsworth, and J. M. Bewley. 2016. A validation of technologies monitoring dairy cow feeding, ruminating, and lying behaviors. J. Dairy Sci. 99:74587466. https://doi.org/10.3168/jds.2015-10843.

Bowman, G. R., K. A. Beauchemin, and J. A. Shelford. 2003. Fibrolytic enzymes and parity effects on feeding behavior, salivation, and ruminal $\mathrm{pH}$ of lactating dairy cows. J. Dairy Sci. 86:565-575. https://doi.org/10.3168/jds.S0022-0302(03)73635-2.

Byskov, M. V., E. Nadeau, B. E. O. Johansson, and P. Nørgaard. 2015. Variations in automatically recorded rumination time as explained by variations in intake of dietary fractions and milk production, and between-cow variation. J. Dairy Sci. 98:3926-3937. https:// doi.org/10.3168/jds.2014-8012.

Campling, R. C., and C. A. Morgan. 1981. Eating behaviour of housed dairy cows-A review. Dairy Sci. Abstr. 43:57-63.

Cao, Z., M. Ma, P. Ji, and S. Li. 2010. Effects of maize silage particle size and feeding method on ruminal fermentation, chewing activity and passage rate of lactation cows. J. Anim. Vet. Adv. 9:374-383. https://doi.org/10.3923/javaa.2010.374.383.

Cassida, K. A., and M. R. Stokes. 1986. Eating and resting salivation in early lactation dairy cows. J. Dairy Sci. 69:1282-1292. https:// doi.org/10.3168/jds.S0022-0302(86)80534-3.

Church, D. C. 1975. Ingestion and mastication of feed. Pages 46-60 in Digestive Physiology and Nutrition of Ruminants. Vol 1. Digestive Physiology. 2nd ed. D. C. Church, ed. O \& B Books, Corvallis, OR.

Clément, P., R. Guatteo, L. Delaby, B. Rouillé, A. Chanvallon, J. M. Philipot, and N. Bareille. 2014. Short communication: Added value of rumination time for the prediction of dry matter intake in lactating dairy cows. J. Dairy Sci. 97:6531-6535. https://doi.org/ $10.3168 /$ jds.2013-7860. 
Connor, E. E. 2015. Improving feed efficiency in dairy production: Challenges and possibilities. Animal 9:395-408. https://doi.org/10 $.1017 /$ S1751731114002997.

Cotanch, K. W., and R. J. Grant. 2006. Measuring physically effective fiber on-farm to predict cow response. Pages 151-160 in Proc. Cornell Nutr. Conf. Feed Manuf., East Syracuse, NY. Accessed Nov. 28, 2017. www.whminer.org/pdfs/Miner\%20peNDF\%20CNC $\% 202006$.pdf.

Crossley, R. E., A. Harlander-Matauschek, and T. J. DeVries. 2017. Variability in behavior and production among dairy cows fed under differing levels of competition. J. Dairy Sci. 100:3825-3838. https://doi.org/10.3168/jds.2016-12108.

Dado, R. G., and M. S. Allen. 1994. Variation in and relationships among feeding, chewing, and drinking variables for lactating dairy cows. J. Dairy Sci. 77:132-144. https://doi.org/10.3168/jds.S0022 -0302(94)76936-8.

Dann, H. M., S. M. Fredin, K. W. Cotanch, R. J. Grant, C. Kokko, P. Ji, and K. Fujita. 2015. Effects of corn-based reduced-starch diets using alternative carbohydrate sources on performance of lactating Holstein cows. J. Dairy Sci. 98:4041-4054. https://doi.org/10 $.3168 /$ jds.2014-9078.

De Boever, J. L., J. I. Andries, D. L. De Brabander, B. G. Cottyn, and F. X. Buysse. 1990. Chewing activity in ruminants as a measure of its physical structure - A review of factors affecting it. Anim. Feed Sci. Technol. 27:281-291. https://doi.org/10.1016/0377 -8401(90)90143-V.

De Mol, R. M., R. M. A. Goselink, J. W. Van Riel, H. M. Knijn, and A. T. M. Van Knegsel. 2016. The relation between eating time and feed intake of dairy cows. Pages 387-392 in Proc. Precision Dairy Farming Conf. Wageningen Academic Publishers, Wageningen, the Netherlands. https://doi.org/10.3920/978-90-8686-829-2.

DeVries, T. J., K. A. Beauchemin, F. Dohme, and K. S. SchwartzkopfGenswein. 2009. Repeated ruminal acidosis challenges in lactating dairy cows at high and low risk for developing acidosis: Feeding, ruminating, and lying behavior. J. Dairy Sci. 92:5067-5078. https://doi.org/10.3168/jds.2009-2102.

DeVries, T. J., M. A. G. von Keyserlingk, and D. M. Weary. 2004. Effect of feeding space on the inter-cow distance, aggression, and feeding behavior of free-stall housed lactating dairy cows. J. Dairy Sci. 87:1432-1438. https://doi.org/10.3168/jds.S0022 -0302(04)73293-2.

Dijkstra, J., J. L. Ellis, E. Kebreab, A. B. Strathe, S. López, J. France, and A. Bannink. 2012. Ruminal pH regulation and nutritional consequences of low pH. Anim. Feed Sci. Technol. 172:22-33. https:// doi.org/10.1016/j.anifeedsci.2011.12.005.

Dolecheck, K. A., W. J. Silvia, G. Heersche Jr., Y. M. Chang, D. L. Ray, A. E. Stone, B. A. Wadsworth, and J. M. Bewley. 2015. Behavioral and physiological changes around estrus events identified using multiple automated monitoring technologies. J. Dairy Sci. 98:8723-8731. https://doi.org/10.3168/jds.2015-9645.

Dong, R. L., G. E. Chibisa, and K. A. Beauchemin. 2018. Estimating optimal observational sampling frequency of behaviors for cattle fed high and low forage diets. J. Anim. Sci. 96:783-796. https:// doi.org/10.1093/jas/skx073.

Dulphy, J. P., B. Remond, and M. Theriez. 1979. Ingestive behaviour and related activities in ruminants. Pages 103-122 in Digestive Physiology and Metabolism in Ruminants. Proc. 5th Int. Symp. Ruminant Physiology. Y. Ruckebusch and P. Thivend, ed. Springer, Berlin, Germany.

Egert, A. M., J. L. Klotz, K. R. McLeod, and D. L. Harmon. 2014. Development of a methodology to measure the effect of ergot alkaloids on forestomach motility using real-time wireless telemetry. Front Chem. 2:90. https://doi.org/10.3389/fchem.2014.00090.

Fitzpatrick, C. E., N. Chapinal, C. S. Petersson-Wolfe, T. J. DeVries, D. F. Kelton, T. F. Duffield, and K. E. Leslie. 2013. The effect of meloxicam on pain sensitivity, rumination time, and clinical signs in dairy cows with endotoxin-induced clinical mastitis. J. Dairy Sci. 96:2847-2856. https://doi.org/10.3168/jds.2012-5855.

Fustini, M., A. Palmonari, G. Canestrari, E. Bonfante, L. Mammi, M. T. Pacchioli, G. C. J. Sniffen, R. J. Grant, K. W. Cotanch, and A. Formigon. 2017. Effect of undigested neutral detergent fiber con- tent of alfalfa hay on lactating dairy cows: Feeding behavior, fiber digestibility, and lactation performance. J. Dairy Sci. 100:44754483. https://doi.org/10.3168/jds.2016-12266.

Gasa, J., K. Holtenius, J. D. Sutton, M. S. Dhanoa, and D. J. Napper. 1991. Rumen fill and digesta kinetics in lactating Friesian cows given two levels of concentrates with two types of grass silage ad lib. Br. J. Nutr. 66:381-398.

Gill, J., R. C. Campling, and D. R. Westgarth. 1966. A study of chewing during eating in the cow. Br. J. Nutr. 20:13-23. https://do .org/10.1079/BJN19660004

Goldhawk, C., K. Schwartzkopf-Genswein, and K. A. Beauchemin. 2013. Technical note: Validation of rumination collars for beef cattle. J. Anim. Sci. 91:2858-2862. https://doi.org/10.2527/jas .2012-5908.

Grant, R. J., V. F. Colenbrander, and J. L. Albright. 1990. Effect of particle size of forage and rumen cannulation upon chewing activity and laterality in dairy cows. J. Dairy Sci. 73:3158-3164. https://doi.org/10.3168/jds.S0022-0302(90)79005-4.

Hämäläinen, W., S. Ruuska, T. Kokkonen, S. Orkola, and J. Mononen. 2016. Measuring behaviour accurately with instantaneous sampling: A new tool for selecting appropriate sampling intervals. Appl. Anim. Behav. Sci. 180:166-173. https://doi.org/10.1016/j .applanim.2016.04.006.

Heinrichs, J. 2013. The Penn State Particle Separator. Accessed Nov 28, 2017. https://extension.psu.edu/penn-state-particle-separator \#section-1.

Hofmann, R. R. 1988. Anatomy of the gastro-intestinal tract. Pages 14-43 in The Ruminant Animal: Digestive Physiology and Nutrition. D. C. Church, ed. Prentice Hall, Englewood Cliffs, NJ.

Huber, T. L. 1976. Physiological effects of acidosis on feedlot cattle. J. Anim. Sci. 43:902-909. https://doi.org/10.2527/jas1976.434902x.

Huws, S. A., O. L. Mayorga, M. K. Theodorou, L. A. Onime, E. J. Kim, A. H. Cookson, C. J. Newbold, and A. H. Kingston-Smith. 2013. Successional colonization of perennial ryegrass by rumen bacteria. Lett. Appl. Microbiol. 56:186-196. https://doi.org/10 $.1111 /$ lam.12033.

Jensen, L. M., B. Markussen, N. I. Nielsen, E. Nadeau, M. R. Weisbjerg, and P. Nørgaard. 2016. Description and evaluation of a net energy intake model as a function of dietary chewing index. J. Dairy Sci. 99:8699-8715. https://doi.org/10.3168/jds.2015-10389.

Jiang, F. G., X. Y. Lin, Z. G. Yan, Z. Y. Hu, G. M. Liu, Y. D. Sun, X. W. Liu, and Z. H. Wang. 2017. Effect of dietary roughage level on chewing activity, ruminal $\mathrm{pH}$, and saliva secretion in lactating Holstein cows. J. Dairy Sci. 100:2660-2671. https://doi.org/10 .3168/jds.2016-11559.

Kahyani, A., G. R. Ghorbani, M. Khorvash, S. M. Nasrollahi, and K. A. Beauchemin. 2013. Effects of alfalfa hay particle size in high concentrate diets supplemented with unsaturated fat: Chewing behavior, total tract digestibility and milk production of dairy cows. J. Dairy Sci. 96:7110-7119. https://doi.org/10.3168/jds.2012 -6462 .

Kammes, K. L., and M. S. Allen. 2012. Nutrient demand interacts with grass particle length to affect digestion responses and chewing activity in dairy cows. J. Dairy Sci. 95:807-823. https://doi .org/10.3168/jds.2011-4588.

Kaufman, E. I., V. H. Asselstine, S. J. LeBlanc, T. F. Duffield, and T. J. DeVries. 2018. Association of rumination time and health status with milk yield and composition in early-lactation dairy cows. J. Dairy Sci. 101:462-471. https://doi.org/10.3168/jds.2017-12909.

Kaufman, E. I., S. J. LeBlanc, B. W. McBride, T. F. Duffield, and T. J. DeVries. 2016. Association of rumination time with subclinical ketosis in transition dairy cows. J. Dairy Sci. 99:5604-5618. https://doi.org/10.3168/jds.2015-10509.

King, M. T. M., R. E. Crossley, and T. J. DeVries. 2016. Impact of timing of feed delivery on the behavior and productivity of dairy cows. J. Dairy Sci. 99:1471-1482. https://doi.org/10.3168/jds.2015 -9790 .

King, M. T. M., K. M. Dancy, S. J. LeBlanc, E. A. Pajor, and T. J. DeVries. 2017. Deviations in behavior and productivity data before diagnosis of health disorders in cows milked with an au- 
tomated system. J. Dairy Sci. 100:8358-8371. https://doi.org/10 .3168/jds.2017-12723.

Kononoff, P. J., H. Lehman, and A. Heinrichs. 2002. Technical noteA comparison of methods used to measure eating and ruminating activity in confined dairy cattle. J. Dairy Sci. 85:1801-1803. https://doi.org/10.3168/jds.S0022-0302(02)74254-9.

Kononoff, P. J., and A. J. Heinrichs. 2003. The effect of reducing alfalfa haylage particle size on cows in early lactation. J. Dairy Sci. 86:1445-1457. https://doi.org/10.3168/jds.S0022-0302(03)73728 $-\mathrm{X}$.

Kononoff, P. J., A. J. Heinrichs, and D. R. Buckmaster. 2003a. Modification of the Penn State Particle Separator and the effects of moisture content on its measurements. J. Dairy Sci. 86:1858-1863. https://doi.org/10.3168/jds.S0022-0302(03)73773-4.

Kononoff, P. J., A. J. Heinrichs, and H. A. Lehman. 2003b. The effect of corn silage particle size on eating behavior, chewing activities, and rumen fermentation in lactating dairy cows. J. Dairy Sci. 86:3343-3353. https://doi.org/10.3168/jds.S0022-0302(03)73937 $-\mathrm{X}$.

Kovács, L., F. L. Kézér, F. Ruff, and O. Szenci. 2017. Rumination time and reticuloruminal temperature as possible predictors of dystocia in dairy cows. J. Dairy Sci. 100:1568-1579. https://doi.org/10 $.3168 /$ jds.2016-11884.

Kowsar, R., G. R. Ghorbani, M. Alikhani, M. Khorvash, and A. Nikkhah. 2008. Corn silage partially replacing short alfalfa hay to optimize forage use in total mixed rations for lactating cows. J. Dairy Sci. 91:4755-4764. https://doi.org/10.3168/jds.2008-1302.

Krause, K. M., D. K. Combs, and K. A. Beauchemin. 2002a. Effects of forage particle size and grain fermentability in midlactation cows. I. Milk production and diet digestibility. J. Dairy Sci. 85:19361946. https://doi.org/10.3168/jds.S0022-0302(02)74270-7.

Krause, K. M., D. K. Combs, and K. A. Beauchemin. 2002b. Effects of forage particle size and grain fermentability in midlactation cows: II. Ruminal pH and chewing activity. J. Dairy Sci. 85:1947-1957. https://doi.org/10.3168/jds.S0022-0302(02)74271-9.

Leek, B. F. 1986. Sensory receptors in the ruminant alimentary tract. Pages 3-17 in Control of Digestion and Metabolism in Ruminants: Proceedings of the Sixth International Symposium on Ruminant Physiology. L. P. Milligan, W. L. Grovum, and A. Dobson, ed. Prentice-Hall, Englewood Cliffs, NJ.

Leng, R. A. 2014. Interactions between microbial consortia in biofilms: A paradigm shift in rumen microbial ecology and enteric methane mitigation. Anim. Prod. Sci. 54:519-543. https://doi.org/10.1071/ AN13381.

Liboreiro, D. N., K. S. Machado, P. R. B. Silva, M. M. Maturana, T. K. Nishimura, A. P. Brandão, M. I. Endres, and R. C. Chebel. 2015. Characterization of peripartum rumination and activity of cows diagnosed with metabolic and uterine diseases. J. Dairy Sci. 98:6812-6827. https://doi.org/10.3168/jds.2014-8947.

Maekawa, M., K. A. Beauchemin, and D. A. Christensen. 2002a. Effect of concentrate level and feeding management on chewing activities, saliva production, and ruminal $\mathrm{pH}$ of lactating dairy cows. J. Dairy Sci. 85:1165-1175. https://doi.org/10.3168/jds.S0022 $-0302(02) 74179-9$

Maekawa, M., K. A. Beauchemin, and D. A. Christensen. 2002b. Chewing activity, saliva production, and ruminal $\mathrm{pH}$ of primiparous and multiparous lactating dairy cows. J. Dairy Sci. 85:11761182. https://doi.org/10.3168/jds.S0022-0302(02)74180-5.

Mason, P. M., and D. C. Stuckey. 2016. Biofilms, bubbles and boundary layers-A new approach to understanding cellulolysis in anaerobic and ruminant digestion. Water Res. 104:93-100. https:// doi.org/10.1016/j.watres.2016.07.063.

Maulfair, D. D., M. Fustini, and A. J. Heinrichs. 2011. Effect of varying total mixed ration particle size on rumen digesta and fecal particle size and digestibility in lactating dairy cows. J. Dairy Sci. 94:3527-3536. https://doi.org/10.3168/jds.2010-3718.

Mertens, D. R. 1997. Creating a system for meeting the fiber requirements of dairy cows. J. Dairy Sci. 80:1463-1481. https://doi.org/ 10.3168/jds.S0022-0302(97)76075-2.

Miller-Cushon, E. K., and T. J. DeVries. 2017. Short communication: Associations between feed push-up frequency, feeding and lying behavior, and milk yield and composition of dairy cows. J. Dairy Sci. 100:2213-2218. https://doi.org/10.3168/jds.2016-12004.

Munksgaard, L., M. B. Jensen, L. J. Pedersen, S. W. Hansen, and L. Matthews. 2005. Quantifying behavioural priorities-Effects of time constraints on behaviour of dairy cows, Bos taurus. Appl. Anim. Behav. Sci. 93:3-14.

Nasrollahi, S. M., M. Imani, and Q. Zebeli. 2016. A meta-analysis and meta-regression of the impact of particle size, level, source and preservation method of forages on chewing behavior and ruminal fermentation in dairy cows. Anim. Feed Sci. Technol. 219:144-158. https://doi.org/10.1016/j.anifeedsci.2016.06.012.

Negussie, E., Y. de Haas, F. Dehareng, R. J. Dewhurst, J. Dijkstra, N. Gengler, D. P. Morgavi, H. Soyeurt, S. van Gastelen, T. Yan, and F. Biscarini. 2017. Large-scale indirect measurements for enteric methane emissions in dairy cattle: A review of proxies and their potential for use in management and breeding decisions. J. Dairy Sci. 100:2433-2453. https://doi.org/10.3168/jds.2016-12030.

Nogami, H., S. Arai, H. Okada, L. Zhan, and T. Itoh. 2017. Minimized bolus-type wireless sensor node with a built-in three-axis acceleration meter for monitoring a cow's rumen conditions. Sensors (Basel) 17:E687. https://doi.org/10.3390/s17040687.

Nørgaard, P., E. Nadeau, and A. T. Randby. 2011. A new Nordic structure evaluation system for diets fed to dairy cows: A meta analysis. Pages 127-132 in NorFor-The Nordic Feed Evaluation System. H. Volden and A. H. Gustafsson, ed. Springer, Berlin, Germany.

Okine, E. K., G. W. Mathison, and R. T. Hardin. 1989. Effects of changes in frequency of reticular contractions on fluid and particulate passage rates in cattle. J. Anim. Sci. 67:3388-3396. https:// doi.org/10.2527/jas1989.67123388x.

Overton, M. W., W. M. Sischo, G. D. Temple, and D. A. Moore. 2002. Using time-lapse video photography to assess dairy cattle lying behavior in a free-stall barn. J. Dairy Sci. 85:2407-2413. https:// doi.org/10.3168/jds.S0022-0302(02)74323-3.

Pahl, C., E. Hartung, A. Grothmann, K. Mahlkow-Nerge, and A. Haeussermann. 2014. Rumination activity of dairy cows in the 24 hours before and after calving. J. Dairy Sci. 97:6935-6941. https:// doi.org/10.3168/jds.2014-8194.

Pahl, C., E. Hartung, K. Mahlkow-Nerge, and A. Haeussermann. 2015. Feeding characteristics and rumination time of dairy cows around estrus. J. Dairy Sci. 98:148-154. https://doi.org/10.3168/jds.2014 -8025 .

Paudyal, S., F. Maunsell, J. Richeson, C. Risco, A. Donovan, and P. Pinedo. 2016. Peripartal rumination dynamics and health status in cows calving in hot and cool seasons. J. Dairy Sci. 99:9057-9068. https://doi.org/10.3168/jds.2016-11203.

Proudfoot, K. L., D. M. Veira, D. M. Weary, and M. A. G. von Keyserlingk. 2009. Competition at the feed bunk changes the feeding, standing, and social behavior of transition dairy cows. J. Dairy Sci. 92:3116-3123. https://doi.org/10.3168/jds.2008-1718.

Reith, S., H. Brandt, and S. Hoy. 2014. Simultaneous analysis of activity and rumination time, based on collar-mounted sensor technology, of dairy cows over the peri-estrus period. Livest. Sci. 170:219 227. https://doi.org/10.1016/j.livsci.2014.10.013.

Reith, S., and S. Hoy. 2012. Relationship between daily rumination time and estrus of dairy cows. J. Dairy Sci. 95:6416-6420. https:// doi.org/10.3168/jds.2012-5316.

Roessen, J., E. Harty, and C. Beirne. 2015. MooMonitor+ smart sensing technology and big data-Resting time as an indicator for welfare status on farms. Pages 99-102 in Performance Recording in the Genotyped World. ICAR Technical Series No. 19. Z. Kowalski, N. Petreny, M. Burke, P. Bucek, L. Journaux, M. Coffey, C. Hunlun, and D. Radzio, ed. International Committee for Animal Recording, Krakow, Poland.

Ruckebusch, Y. 1988. Motility of the gastro-intestinal tract. Pages 64-107 in The Ruminant Animal: Digestive Physiology and Nutrition. D. C. Church, ed. Prentice-Hall, Englewood Cliffs, NJ.

Rutten, C. J., A. G. J. Velthuis, W. Steeneveld, and H. Hogeveen. 2013. Invited review: Sensors to support health management on dairy farms. J. Dairy Sci. 96:1928-1952. https://doi.org/10.3168/ jds.2012-6107. 
Sá Neto, A., A. W. Bispo, D. Junges, A. K. Berch, M. Zopollatto, J. L. P. Daniel, and L. G. Nussio. 2014. Exchanging physically effective neutral detergent fiber does not affect chewing activity and performance of late-lactation dairy cows fed corn and sugarcane silages. J. Dairy Sci. 97:7012-7020. https://doi.org/10.3168/jds .2013-7856.

Schadt, I., J. D. Ferguson, G. Azzaro, R. Petriglieri, M. Caccamo, P. Van Soest, and G. Licitra. 2012. How do dairy cows chew?-Particle size analysis of selected feeds with different particle length distributions and of respective ingested bolus particles. J. Dairy Sci. 95:4707-4720. https://doi.org/10.3168/jds.2011-5118.

Schirmann, K., N. Chapinal, D. M. Weary, W. Heuwieser, and M. A. G. von Keyserlingk. 2012. Rumination and its relationship to feeding and lying behavior in Holstein dairy cows. J. Dairy Sci. 95:3212-3217. https://doi.org/10.3168/jds.2011-4741.

Schirmann, K., N. Chapinal, D. M. Weary, L. Vickers, and M. A G. von Keyserlingk. 2013. Short communication: Rumination and feeding behavior before and after calving in dairy cows. J. Dairy Sci. 96:7088-7092.

Schirmann, K., M. A. von Keyserlingk, D. M. Weary, D. M. Veira, and W. Heuwieser. 2009. Technical note: Validation of a system for monitoring rumination in dairy cows. J. Dairy Sci. 92:6052-6055. https://doi.org/10.3168/jds.2009-2361.

Schirmann, K., D. M. Weary, W. Heuwieser, N. Chapinal, R. L. A. Cerri, and M. A. G. von Keyserlingk. 2016. Short communication: Rumination and feeding behaviors differ between healthy and sick dairy cows during the transition period. J. Dairy Sci. 99:99179924. https://doi.org/10.3168/jds.2015-10548.

Seo, S., C. Lanzas, L. O. Tedeschi, A. N. Pell, and D. G. Fox. 2009 Development of a mechanistic model to represent the dynamics of particle flow out of the rumen and to predict rate of passage of forage particles in dairy cattle. J. Dairy Sci. 92:3981-4000. https:// doi.org/10.3168/jds.2006-799.

Siivonen, J., S. Taponen, M. Hovinen, M. Pastell, B. J. Lensink, S. Pyörälä, and L. Hänninen. 2011. Impact of acute clinical mastitis on cow behaviour. Appl. Anim. Behav. Sci. 132:101-106. https:// doi.org/10.1016/j.applanim.2011.04.005.

Soita, H. W., D. A. Christensen, and J. J. McKinnon. 2000. Influence of particle size on the effectiveness of the fiber in barley silage. J. Dairy Sci. 83:2295-2300. https://doi.org/10.3168/jds.S0022 -0302(00)75116-2

Soriani, N., G. Panella, and L. Calamari. 2013. Rumination time during the summer season and its relationships with metabolic conditions and milk production. J. Dairy Sci. 96:5082-5094. https://doi .org $/ 10.3168 /$ jds.2013-6620.

Stangaferro, M. L., R. Wijma, L. S. Caixeta, M. A. Al-Abri, and J. O. Giordano. 2016a. Use of rumination and activity monitoring for the identification of dairy cows with health disorders: Part I. Metabolic and digestive disorders. J. Dairy Sci. 99:7395-7410. https:// doi.org/10.3168/jds.2016-10907.

Stangaferro, M. L., R. Wijma, L. S. Caixeta, M. A. Al-Abri, and J. O. Giordano. 2016b. Use of rumination and activity monitoring for the identification of dairy cows with health disorders: Part II. Mastitis. J. Dairy Sci. 99:7411-7421. https://doi.org/10.3168/jds .2016-10908.

Stangaferro, M. L., R. Wijma, L. S. Caixeta, M. A. Al-Abri, and J. O. Giordano. 2016c. Use of rumination and activity monitoring for the identification of dairy cows with health disorders: Part III. Metritis. J. Dairy Sci. 99:7422-7433. https://doi.org/10.3168/jds .2016-11352.

Stone, A. E., B. W. Jones, C. A. Becker, and J. M. Bewley. 2017. Influence of breed, milk yield, and temperature-humidity index on dairy cow lying time, neck activity, reticulorumen temperature, and rumination behavior. J. Dairy Sci. 100:2395-2403. https://doi .org/10.3168/jds.2016-11607.

Sutherland, T. M. 1988. Particle separation in the forestomachs of sheep. Pages 43-73 in Aspects of Digestive Physiology in Ruminants. A. Dobson and M. J. Dobson, ed. Cornell Univ. Press, Ithaca, NY.
Suzuki, S., H. Fujita, and Y. Shinde. 1969. Change in the rate of eating during a meal and the effect of the interval between meals on the rate at which cows eat roughages. Anim. Prod. 11:29-41.

Tafaj, M., Q. Zebeli, C. Baes, H. Steingass, and W. Drochner. 2007. A meta-analysis examining effects of particle size of total mixed rations on intake, rumen digestion and milk production in highyielding dairy cows in early lactation. Anim. Feed Sci. Technol 138:137-161. https://doi.org/10.1016/j.anifeedsci.2007.06.020.

Vasilatos, R., and P. J. Wangsness. 1980. Feeding behavior of lactating dairy cows as measured by time-lapse photography. J. Dairy Sci 63:412-416. https://doi.org/10.3168/jds.S0022-0302(80)82948-1.

Waldo, D. R., L. W. Smith, E. L. Cox, B. T. Weinland, and H. L. Lucas. 1971. Logarithmic normal distribution for description of sieved forage materials. J. Dairy Sci. 54:1465-1469. https://doi .org/10.3168/jds.S0022-0302(71)86048-4.

Walker, S. L., R. F. Smith, J. E. Routly, D. N. Jones, M. J. Morris, and H. Dobson. 2008. Lameness, activity time-budgets, and estrus expression in dairy cattle. J. Dairy Sci. 91:4552-4559. https://doi .org/10.3168/jds.2008-1048.

Watt, L. J. C. E. F. Clark, G. L. Krebs, C. E. Petzel, S. Nielsen, and S. A. Utsumi. 2015. Differential rumination, intake, and enteric methane production of dairy cows in a pasture-based automatic milking system. J. Dairy Sci. 98:7248-7263. https://doi.org/10 $.3168 /$ jds.2015-9463.

Welch, J. G. 1982. Rumination, particle size and passage from the rumen. J. Anim. Sci. 54:885-894. https://doi.org/10.2527/jas1982 $.544885 x$.

White, R. R., M. B. Hall, J. L. Firkins, and P. J. Kononoff. 2017. Physically adjusted neutral detergent fiber system for lactating dairy cow rations. I: Deriving equations that identify factors that influence effectiveness of fiber. J. Dairy Sci. 100:9551-9568. https://doi.org/10.3168/jds.2017-12766.

Yang, W. Z., and K. A. Beauchemin. 2006. Increasing the physically effective fiber content of dairy cow diets may lower efficiency of feed use. J. Dairy Sci. 89:2694-2704. https://doi.org/10.3168/jds .S0022-0302(06)72345-1.

Yang, W. Z., and K. A. Beauchemin. 2007. Altering physically effective fiber intake through forage proportion and particle length: Chewing and ruminal pH. J. Dairy Sci. 90:2826-2838. https://doi .org/10.3168/jds.2007-0032.

Yang, W. Z., and K. A. Beauchemin. 2009. Increasing physically effective fiber content of dairy cow diets through forage proportion versus forage chop length: Chewing and ruminal $\mathrm{pH}$. J. Dairy Sci. 92:1603-1615. https://doi.org/10.3168/jds.2008-1379.

Yang, W. Z., K. A. Beauchemin, and L. M. Rode. 2001a. Effects of grain processing, forage to concentrate ratio, and forage particle size on rumen $\mathrm{pH}$ and digestion by dairy cows. J. Dairy Sci. 84:2203-2216. https://doi.org/10.3168/jds.S0022-0302(01)74667 $-\mathrm{X}$

Yang, W. Z., K. A. Beauchemin, and L. M. Rode. 2001b. Barley processing, forage:concentrate, and forage length effects on chewing and digesta passage in lactating cows. J. Dairy Sci. 84:2709-2720. https://doi.org/10.3168/jds.S0022-0302(01)74725-X.

Zebeli, Q.. J. R. Aschenbach, M. Tafaj, J. Boguhn, B. N. Ametaj, and W. Drochner. 2012. Invited review: Role of physically effective fiber and estimation of dietary fiber adequacy in high-producing dairy cattle. J. Dairy Sci. 95:1041-1056. https://doi.org/10.3168/ jds.2011-4421.

Zebeli, Q., M. Tafaj, H. Steingass, B. Metzler, and W. Drochner. 2006. Effects of physically effective fiber on digestive processes and milk fat content in early lactating dairy cows fed total mixed rations. J. Dairy Sci. 89:651-668. https://doi.org/10.3168/jds.S0022 -0302(06)72129-4.

Zhang, S. Z., G. B. Penner, M. Abdelqader, and M. Oba. 2010. Effects of feeding alfalfa hay on chewing, rumen $\mathrm{pH}$, and milk fat concentration of dairy cows fed wheat dried distillers grains with solubles as a partial substitute for barley silage. J. Dairy Sci. 93:3243-3252. https://doi.org/10.3168/jds.2009-3011. 